IZA DP No. 4116

\title{
Cultures, Clashes and Peace
}

\section{Erin Fletcher}

Murat lyigun

April 2009 


\title{
Cultures, Clashes and Peace
}

\author{
Erin Fletcher \\ University of Colorado
}

Murat lyigun

University of Colorado, CID, Harvard University and IZA

\section{Discussion Paper No. 4116 \\ April 2009}

\author{
IZA \\ P.O. Box 7240 \\ 53072 Bonn \\ Germany \\ Phone: +49-228-3894-0 \\ Fax: +49-228-3894-180 \\ E-mail: iza@iza.org
}

\begin{abstract}
Any opinions expressed here are those of the author(s) and not those of IZA. Research published in this series may include views on policy, but the institute itself takes no institutional policy positions.

The Institute for the Study of Labor (IZA) in Bonn is a local and virtual international research center and a place of communication between science, politics and business. IZA is an independent nonprofit organization supported by Deutsche Post Foundation. The center is associated with the University of Bonn and offers a stimulating research environment through its international network, workshops and conferences, data service, project support, research visits and doctoral program. IZA engages in (i) original and internationally competitive research in all fields of labor economics, (ii) development of policy concepts, and (iii) dissemination of research results and concepts to the interested public.
\end{abstract}

IZA Discussion Papers often represent preliminary work and are circulated to encourage discussion. Citation of such a paper should account for its provisional character. A revised version may be available directly from the author. 


\section{ABSTRACT}

\section{Cultures, Clashes and Peace*}

Ethnic and religious fractionalization have important effects on economic growth and development, but their role in internal violent conflicts has been found to be negligible and statistically insignificant. These findings have been invoked in refutation of the Huntington hypothesis, according to which differences of ethnic, religious and cultural identities are the ultimate determinants of conflict. However, fractionalization in all its demographic forms is endogenous in the long run. In this paper, we empirically investigate the impact of violent conflicts on ethno-religious fractionalization. The data involve 953 conflicts that took place in 52 countries in Europe, Africa and the Middle East between 1400 CE and 1900 CE. Besides a variety of violent confrontations ranging from riots, revolts and power wars between secular sovereigns, the data cover religiously motivated confrontations. We document that countries in which Muslim on Christian wars unfolded more frequently are significantly more religiously homogenous today. In contrast, those places where Protestant versus Catholic confrontations occurred or Jewish pogroms took place are more fractionalized, both ethnically and religiously. And the longer were the duration of all such conflicts and violence, the less fractionalized countries are today. These results reveal that the demographic structure of countries in Europe, the Middle East and North Africa still bear the traces of a multitude of ecclesiastical and cultural clashes that occurred throughout the course of history. They also suggest that endogeneity could render the relationship between fractionalization and the propensity of internal conflict statistically insignificant. Finally, instrumenting for conflicts with some geographic attributes and accounting for the endogeneity of fractionalization with respect to ecclesiastical conflicts shows that religous fractionalization likely has negative effects on economic growth.

JEL Classification: $\quad$ C72, D74, N33, N43, O10

Keywords: conflict, religion, institutions, economic development

Corresponding author:

Murat lyigun

University of Colorado at Boulder

Department of Economics

Campus Box 256

Boulder, CO 80309-0256

USA

E-mail: murat.iyigun@colorado.edu

\footnotetext{
*We gratefully acknowledge Rachel McCleary's detailed comments and critique although, as usual, all errors and speculations are ours alone.
} 


\section{Introduction}

Religious and ethnic fractionalization play a prominent role in the empirical growth and development literature and have been repeatedly shown to have a wide array of effects. In various studies, ethno-linguistic differences have been identified as having had detrimental effects on sociopolitical cohesion, thereby eroding the quality of institutions, the commensurate government policies and long-run economic growth. ${ }^{1}$ Religious fractionalization, in contrast, often exerts a positive if not always statistically significant effect on economic growth, presumably because such fractionalization is an indicator of sociopolitical tolerance and religious freedoms. ${ }^{2}$

While the economic literature has identified that fractionalization has an indirect influence on economic development and growth, a host of papers has shown that the standard measures of ethnic or religious fractionalization have a quantitatively and statistically negligible impact on the propensity of violent conflicts within countries. ${ }^{3}$ It is on this basis that economists and political scientists have often refuted the 'Huntington hypothesis' whereby differences of ethnic, religious and cultural identities are the ultimate determinants of conflict. ${ }^{4}$

The observed levels of fractionalization are clearly endogenous in the long run. Thus, the standard approach to estimating the impact of fractionalization on institutional quality and economic growth has involved maintaining time horizons that are long enough to isolate the impact of fractionalization on economic outcomes, but are also short enough that measures of fractionalization remain more or less constant. In practice, this strategy has yielded studies that cover two or three decades. Still, the extent to which ethnic, linguistic or religious fractionalization evolves and changes over time is subject to some debate, although there is more of a consensus that religious fractionalization is the most malleable and responsive to changes in the external environment. ${ }^{5}$

In this paper, we examine the long-run determinants of contemporary fractionaliza-

\footnotetext{
${ }^{1}$ Easterly and Levine (1997), Alesina et al. (1999, 2003), La Porta (et al., 1999) and Mauro (1995). For a salient theoretical treatment, see Caselli and Coleman (2006).

${ }^{2}$ For further details, see Alesina et al. (2003).

${ }^{3}$ Fearon and Laitin (2003), Collier and Hoeffler (2005, 2007), Miguel et al. (2004) and Ray (2005).

${ }^{4}$ Huntington (1996).

${ }^{5}$ See, for instance, Alesina et al. (2003). A dissenting view is provided by Campos and Kuzeyev (2007) who argue that ethnic fractionalization evolved more rapidly than linguistic and religious fractionalization in 26 former communist countries over the period between 1989 and 2002.
} 
tion across countries along ethnic, linguistic and religious dimensions. We particularly focus on the impact of violent confrontations over the course of medieval and postIndustrial Revolution history on religious fractionalization in Europe, the Middle East, the Near East and North Africa. Covering 953 violent confrontations that took place in 52 countries in the aforementioned geographies over half a millennium between 1400 and $1900 \mathrm{CE}$, we document that the frequencies and types of conflict influenced contemporary levels of religious and to some extent ethnic and linguistic fractionalization too.

For example, we find that the frequency of Muslim on Christian wars within a country's borders is a statistically significant and positive predictor of its current levels of religious homogeneity; an additional incidence of violent conflict between Muslim and Christian players within the borders of a modern country would have been sufficient to lower its current level of religious fractionalization anywhere between 5 to 10 percent. In contrast, Protestant and Catholic confrontations within each country between the 15th and 19th centuries - and to some extent the incidence of Jewish pogroms toohelped produce more modern-day religious fractionalization, with an additional Catholic on Protestant confrontation accounting for more than 15 percent higher religious fractionalization. In addition, the longer was the duration of all such conflicts and violence, the less fractionalized are countries now.

These results are robust to the inclusion of various control variables such as geographic region dummies, distance to the equator and population. For instance, we verify that distance from the equator is a predictor of ethnic and religious fractionalization, with equatorial distance reducing both. It is also the case that certain geographic regions that are currently more fractionalized religiously and ethnically than others - such as the Balkans and Eastern Europe - also typically have been historical buffer zones in which religious conflicts between Muslims and Christians or Protestants and Catholics were fought with higher frequency as well as longer duration.

Our conclusions are also robust to incorporating a much longer time lag than one century between the measurements of fractionalization and conflict data. In fact, if anything, the empirical results are strengthened using specifications in which 502 observations on violent conflicts that occurred between 1400 to $1600 \mathrm{CE}$ are used as the 
basis of gauging the impact of historical conflicts on cross-country measures of religious fractionalization at the turn of the 21st century.

These findings are relevant for assessing the Huntington hypothesis because they demonstrate that the demographic structure of countries in Europe, the Middle East and North Africa still bear the traces of a multitude of 'ecclesiastical and cultural clashes' that occurred throughout the course of history. More specifically, those geographies where clashes took place more often and with a longer duration between Muslim and Christian 'civilizations' are likely to be the areas that are more homogenous today. Whereas the areas with a more frequent history of conflicts within the Judeo-Christian or Muslim 'civilizations' are more likely to be more heterogenous and fractionalized now. Accordingly, modern-day fractionalization might simply be a manifestation of ethnic and religious groups that have painfully learned to coexist. In contrast, a fairly homogenized country is likely to be a geography where the source of that homogeneity is a historically persistent source of conflict that produced attrition and out-migration. Either way, the likelihood of internal violence and conflict would be lower now, rendering the relationship between fractionalization and the propensity of conflict within countries statistically insignificant.

That ethnic, religious and linguistic cleavages within countries could be sources of violent conflict and internal strife is by now part and parcel of the ubiquitous Huntington hypothesis: "...conflicts occur between groups from different civilizations within a state and between groups which are... attempting to create new states out of the wreckage of the old." What is relatively obscure, however, is that Huntington himself was, at least implicitly, cognizant of the attenuating effects of conflicts in the long run:

"Many countries are divided in that the [ethnic, racial and religious] differences and conflicts among these groups play an important role in the politics of the country. The depth of this division usually varies over time. Deep divisions within a country can lead to massive violence or threaten the country's existence. This latter threat and movements for autonomy or separation are most likely to arise when cultural differences coincide with differences in geographic location. If culture and geography do not coincide, they may be made to coincide through either genocide or forced migration," Huntington 
(1993, p. 137, 208).

Given that the economics literature has long linked the institutional quality of countries and their sociopolitical as well as economic stability to various forms of fractionalization, a salient issue is whether conflicts and religious confrontations have a direct impact on institutions and political systems, or if the impact of violence and religious confrontations solely filters through fractionalization. ${ }^{6}$ While our analysis confirms that ethnic and linguistic fractionalization has a detrimental impact on institutions and the quality of polities across countries, there indeed exists a direct and statistically significant impact of the history of violent conflicts - especially those of a religious nature - on institutions and polities.

The fact that fractionalization is shown to evolve over time and the empirical work below incorporates time lags of anywhere from one to four centuries between the conflict data and fractionalization observations ought to be sufficient to isolate the impact of the former on the latter. But in interpreting empirical work on the relationship between fractionalization and economic outcomes, the conventional inclination is to explore the potential channels of adverse impact via the role of fractionalization in generating conflict. From this perspective, the direction of causality that we advocate here runs counter to such traditional approaches. Be that as it may, it is important to acknowledge that, if historical trends did exist over the very long periods we consider here, they were in the direction of generating higher fractionalization, not less. ${ }^{7}$ As we shall soon elaborate, given our main results - especially those involving the Muslim versus Christian confrontations - such a channel of reverse causality would produce an attenuation bias. This is on account of the fact the argument of reverse causality establishes a positive effect, which runs from higher fractionalization to more frequent conflicts and violence. But in a variety of cases - most notably, regarding the impact of Muslim-Christian confrontations - we find a negative impact of violent conflicts on fractionalization.

Furthermore, as we shall document in Section 3, the historical evidence suggests

\footnotetext{
${ }^{6}$ For the role of social divisions and fractionalization on stability and institutions, see Alesina, Baqir and Easterly (1999), Easterly and Levine (1997), Knack and Keefer (1995).

${ }^{7}$ Direct supporting evidence for the long term evolution of fractionalization is hard to come by. But for the medium term evolutions of ethnic, religious and linguistic fractionalization following the disintegration of authoritarian socialist regimes, see Campos and Kuzeyev (2007).
} 
that there were fundamental changes in the degree of religious and ethnic fractionalization of the specific geographies we study below during the last century, let alone the five centuries preceding it. In the Middle East, Europe, the Near East and parts of northern Africa, which are subject to our analysis, medieval history reveals that religious pluralism came mostly on the back of violent confrontations either due to international political and religious rivalries or as a result of domestic religious splinters. ${ }^{8}$ This is all in the way of arguing that, while fractionalization may be an accurate and significant predictor of social and political conflicts in the short and the medium runs, fractionalization was influenced by violent confrontations in the very long run.

All the same, violent ecclesiastical confrontations are plausibly endogenous too, and it is possible that the historical patterns of ecclesiastical conflicts were shaped by proximity - or lack thereof - to geographic regions that have been pivotal for Judaism, Christianity and Islam, such as Jerusalem, Mecca and Rome. In that case, countries' distance to these ecclesiastical centers could be used as instruments based on the premise that spread and contractions of Judaism, Christianity and Islam historically were predominantly driven by conflicts, so as to make religious, ethnic and even linguistic fractionalization functions of ecclesiastical conflict but not distance to the ecclesiasticallypivotal cities. In this spirit, we ran 3-stage least squares IV regressions, in which we first regressed ecclesiastical conflicts on distance to ecclesiastical centers, we then estimated the impact of conflicts on fractionalization, and we subsequently identified the impact of fractionalization on average economic growth rates. Doing so revealed a negative and statistically significant effect of religious, ethnic and linguistic fractionalization on economic growth.

\section{Some Related Literature}

In addition to the literatures referenced above, the work below relates to other strands in the economics of religion and political economy. First, differences of religion have been documented as important instigators of violent conflict. As Richardson (1960) has shown, differences of Christianity and Islam, have been causes of wars and that, to a weaker extent, "Christianity incited war between its adherents." Similarly, Wilkinson (1980) has claimed that "the propensity of any two groups to fight increases as the differences

\footnotetext{
${ }^{8}$ Iyigun $(2008 \mathrm{a}, \mathrm{b})$.
} 
between them (in language, religion, race, and cultural style) increase." And the more recent political science literature has supplied the view that religion and ethnicity are two fundamental components of 'culture capital', the differences in which that can produce wholesale 'clash of civilizations'. 9

The corollary of such findings were in fact articulated earlier by the likes of Montesquieu, Kant and Angell. Their 'liberal peace' view emphasized that "mutual economic interdependence could be a conduit of peace." Along these lines, Jha (2008) finds some evidence of the view that differences in the degree to which Hindus and Muslims could provide complementary, non-replicable services in the medieval maritime ports of India explain the extent to which religious tolerance could be sustained over the long term. In particular, he shows that medieval trading ports were 25 percent less likely to experience a religious riot between 1850-1950, two centuries after Europeans eliminated Muslim advantages in trade. In a similar vein, Clingingsmith et al. (forthcoming) document that the Muslim pilgrimage of Hajj increases observance of global Islamic practices while decreasing antipathy toward non-Muslims. Their evidence suggests that such changes are due to the interactions among Hajjis from around the world during the Holy Pilgrimage.

Second, we have the political economy literature that incorporates conflict and appropriation into models of production. Haavelmo (1954) was the first to articulate the notion that appropriation and violent conflict over the ownership for resources should be modeled as an alternative to economic production. Later contributions, such as Hirshleifer (1991), Grossman (1994), Grossman and Kim (1995), Grossman and Iyigun (1995, 1997), Skaperdas (1992, 2005), Alesina and Spolaore (2007) and Hafer (2006), built on Haavelmo's original ideas. The work below sits at the junction of these two strands since it is based on the premise that religious, ethnic or more broadly cultural differences could be driven by conflict and war.

There is also an active related strand in the economics of religion. Some papers in this line focus on the supply side, emphasizing how religious norms and denominations evolve (e.g., Barro and McCleary, 2005, Berman, 2000, Ekelund et al., 1996, Ekelund et al., 2002, Iannaccone, 1992). Other papers, in contrast, discuss the demand side (Glaeser

\footnotetext{
${ }^{9}$ The culture capital view of religion has been advocated by, among others, Huntington (1996), Landes (1998), Ingelhart and Baker (2000).
} 
and Sacerdote, 2003, Inglehart and Baker, 2000).

Yet another cluster of work on the economics of religion explores how adherence to different faiths, such as Judaism, Islam or different denominations of Christianity, might have influenced individual behavior and the evolution of sociopolitical institutions (e.g., Greif, 1993, 1994, 2006, Kuran, 2004a, 2005, Becker and Woessmann, 2009, Botticini and Eckstein, 2005, 2007, Glaeser, 2005, Lewis, 2002, Guiso et al., 2003, 2006, Abramitzky, 2008 and Iyigun, 2007, 2008a, 2008b). More generally, this strand falls within the rubric of the economics of culture which advocates the importance of cultural differences in various economic outcomes (Landes, 1998, Temin, 1997, Fernandez et al., 2004, Fernandez, 2007). The work below relates to this strand because it examines the longer-term demographic ramifications of conflicts related to or driven by religious motives.

The remainder of this paper is organized as follows: In Section 3, we review the historical background. In Section 4, we present the baseline findings. In Section 5, we discuss issues of endogeneity as well as robustness, and present some alternative specifications. In Section 6, we conclude.

\section{Historical Background}

Our measures of religious and ethnic fractionalization do not extend back in time for us to control for the dynamics of fractionalization historically. As we have noted above, however, there is somewhat of a consensus that religious fractionalization is more responsive to the external environment than either ethnic or linguistic fractionalization. In any case, we shall now provide some evidence that the geographic areas in the current domain of the 52 countries in our study were most likely to have been uniformly homogenous throughout the 16th century - if not until much later - than they are today.

To start with, consider Europe, the Middle East and North Africa at the turn of the 15th century. At the time, Christianity had been split for close to three and a half centuries along its eastern Orthodox and Roman Catholic denominations. And the Nestorian as well as the Coptic Churches had already split from Rome close to a millennium prior to $1400 \mathrm{CE}$. However, there was little if any geographic overlap in the domain of each of these Christian denominations at the turn of the 15th century. Moreover, while the precedents for the Protestant Reformation had been set in western, northern and central Europe with the Cathar/Albigensian uprisings in $1177 \mathrm{CE}$ as well 
as the Waldensian movement in the same year, Europe west of the Balkan peninsula was quite a homogenous ecclesiastical block within the domain - and under the monopolyof the Roman Catholic Church. (see Moore, 1994, and Rhodes, 2005). In England, it was not until 1534 that fractionalization began in earnest with the Church of England separating from the Roman Catholic Church during the reign of Henry VIII. ${ }^{10}$

In the east, the Ottoman empire had made significant territorial gains in the late 14th century, yielding the geographic areas within what is now Bulgaria, Romania and most of eastern Greece to Ottoman control. The Ottomans followed the traditional Islamic policy of religious tolerance toward the other 'people of the book'. Jews, Christians and other believers of the one true God had the right of protection of their lives, properties and religious freedoms provided that they accepted Ottoman rule and paid the special head tax, cizye. Hence, there is not much on record to suggest that a large number of Balkan Christians converted to Islam, with only some small minority groups, such as the Bogomils of Bosnia, who had been persecuted under Christian rule, having chosen to do so (Shaw, 1976, p. 19). Nor was there any significant amount of resettlement by the Ottoman Muslims within the newly-acquired eastern European territories. While the Balkans are currently one of the most religiously fractionalized geographic regions covered in our study, there is much to suggest that this fractionalization was fairly low and bounded by our contemporary standards throughout the 16th and the 17th centuries. ${ }^{11}$

At the turn of the 16th century, Spain looked like a most homogenous Catholic country. Of course, that was on account of the Spanish Inquisition, under which Monarchs Isabella I of Castile and Ferdinand II of Aragon had begun in 1478 to purge the Iberian peninsula of all religions and Christian denominations except Roman Catholicism. While the inquisition did not officially end until 1834 when Isabel II abolished it, the Muslims and Jews of the peninsula as well as its Christians of rival denominations had relocated

\footnotetext{
${ }^{10} \mathrm{MacCulloch}$ (2003, pp. 193, 194).

${ }^{11}$ Along these lines, there is clear consensus that the Ottomans' deliberate policies of low taxes and religious toleration generally helped to augment religious and ethnic diversity of the Balkans and eastern Europe (Kafadar, 1996, Shaw, 1976, and Karpat, 1974, Faroqhi, 2004, pp. 37 and 64).

It is well known that the Ottomans were directly involved in aiding the relocation of Huguenots from France to Moldavia, then an Ottoman territory. The Ottomans also indirectly supported the Serbian Orthodox immigrants againts the Hapsburgs in some Balkan protectorates.
} 
out of the peninsula entirely by the early 16 th century. ${ }^{12}$

All in all, the geographic areas we cover in this paper were much more homogenous religiously, ethnically and linguistically in the 16th century, and even the 17 th century. There were two primary reasons for this: (i) The Protestant Reformation hadn't yet occurred and most splinter movements within Christianity had to remain underground until late-16th century to mid-17th century, when Protestantism was officially recognized by the Roman Catholic Church. (ii) The Balkans started to come under Ottoman influence in the early 15th century, but the Ottoman control of the peninsula was not complete until much later in the early-16th century. Thus, even though the Balkans started to became religiously and ethnically fractionalized relatively early on, they were fairly homogenous throughout the 16th century and even much later due to the Ottomans' fiscal policies and the decentralized nature of their authority. Moreover, those regions that were most fractionalized at that time included the Balkans as well as northern and western Europe, which are the regions that are still some of the most fractionalized today (more on which below).

In this context, one also needs to bear in mind that fractionalization data are driven, to some significant extent, by the political regimes in effect. In more repressive regimes, the measured fractionalization rates are more likely to be lower than the actual measures. ${ }^{13}$ Hence, the fact that the time period and geographic areas we investigate were unambiguously much less democratic and typically much more repressive prior to 1900 and most certainly before 1600 also suggests more homogeneity back in time.

\section{The Empirical Analysis}

\subsection{Data and Descriptive Statistics}

The primary data source of violent conflicts is the Conflict Catalog by Brecke (1999). It is a comprehensive dataset on violent conflicts in all regions of the world between $1400 \mathrm{CE}$ and the present. It contains a listing of all recorded violent conflicts with a Richardson's magnitude 1.5 or higher that occurred on five continents. ${ }^{14}$ These data are

\footnotetext{
${ }^{12}$ Landes (1998, p. 139).

${ }^{13}$ Alesina et al. (2003).

${ }^{14}$ Brecke uses the definition of violent conflicts supplied by Cioffi-Revilla (1996): "An occurrence of purposive and lethal violence among $2+$ social groups pursuing conflicting political goals that results in fatalities, with at least one belligerent group organized under the command of authoritative leadership.
} 
still under construction, but they are virtually complete for Europe, North Africa and the Near East. We rely on this portion.

For each conflict recorded in the catalog, the primary information covers (i) the number and identities of the parties involved in the conflict; (ii) the common name for the confrontation (if it exists); and (iii) the date(s) of the conflict. On the basis of these data, there also exists derivative information on the duration of the conflict and the number of fatalities, but the latter are only available for less than a third of the sample.

We worked with two cuts of this dataset: one, which covered the five centuries between 1400 and $1900 \mathrm{CE}$, and another that spanned the two hundred years between 1400 and $1600 \mathrm{CE}$. The broader, half a millennium cut yielded a total of 953 conflicts, while the narrower dataset resulted in 502 observations. We then identified the geographic locations of each of these conflicts and assigned them to one of the 52 countries that exist today in Europe, the Middle East, the Near East or North Africa. ${ }^{15}$ Then we augmented this dataset with the fractionalization data constructed by Alesina et al. (2003). For some other peripheral data, such as population measures, polity and democracy scores and city distance calculations, we relied on McEvedy and Jones (1978), the Polity IV Project and City Distance Tool by Geobytes. ${ }^{16}$

Our final data processing step involved classifying conflicts by the actors involved. If a violent conflict pitted a predominantly Muslim society against a Christian one (i.e., the Ottomans versus the Hapsburgs at various occasions during the 16th and 17th centuries or the Russo-Circassian wars between 1832 and 1864), we labeled that conflict as one involving Muslims against Christians; if it involved coreligionist groups (such as the Napoleonic wars in Europe or Russia in the 19th century or the Ottomans against

The state does not have to be an actor. Data can include massacres of unarmed civilians or territorial conflicts between warlords."

Richardson's index corresponds to 32 or more deaths $(\log 32=1.5)$ and the five continents covered are all those that are inhabitable (i.e., Europe, Asia, the Americas, Australia, and Africa).

${ }^{15}$ To be specific, we first identified the theater(s) of conflict for each of the observations in the Brecke dataset using multiple sources, including, but not limited to Oxford Atlas of World History (2002), the Rand McNally Historical Atlas of the World (2005), the Encyclopedia Britannica, Levy (1983) and Shaw (1976). Then, we identified the longitude and latitude of each of the battle or conflict locations. We used that information to tally the different kinds of conflicts and violent confrontations that occurred between 1400 and $1900 \mathrm{CE}$ within the borders of the 52 countries in our sample.

${ }^{16}$ The Polity IV data can be accessed at http://www.systemicpeace.org/polity/polity4.htm and the city distance calculator can be found at http://www.geobytes.com/CityDistanceTool.htm. 
the Safavids or Memluks in the 16th century), then we classified them as Christian versus Christian or Muslim versus Muslim. And for those conflicts which explicitly had a religious dimension (such as the various Protestant or Huguenot revolts against the Catholic establishment in Europe during the 14th, 15th or 16th centuries and various Jewish pogroms that occurred in Europe dating back to the 11th century), we classified them as Catholic-Protestant confrontations or pogroms. ${ }^{17}$

Table 1 lists the key underlying data and Table 2 presents some descriptive statistics. As shown in the first table, countries that are most religiously fractionalized today include the Eastern European and Balkan countries, such as Bosnia \& Herzegovina, Slovakia, Czech Republic, Hungary and Moldova. Interestingly, this is more or less the set of countries that lay in the buffer zone between Christianity and Islam, as defined by Huntington. ${ }^{18}$ There are other highly fractionalized countries located in western and central Europe also, such as the Netherlands, Switzerland, Germany and the United Kingdom, as well as others in the Middle East, such as Jordan and Lebanon. By contrast, those countries that are religiously most homogenous typically have Muslim majorities, such as Algeria, Tunisia, Turkey and Yemen.

While there are a priori reasons to think that the interactions of people with different ethnic or religious backgrounds might have been more frequent in the buffer zones, they do not necessarily suggest the higher frequency of ethnic and religious interactions produced a positive or negative net impact on fractionalization in the buffer territories. On the one hand, it could have been that minority religions were either exterminated or

\footnotetext{
${ }^{17}$ Of course, there are various other finer or broader classification criteria we could employ. For example, among Muslim versus Muslim conflicts, we could distinguish those confrontations that occurred between the Shi'a versus the Sunni. Or, within Christianity, we could identify those confrontations which pitted eastern Orthodox groups against Catholic societies. In the work below, we have chosen to focus instead on categories of conflict that had higher frequency or relatively more significance historically, but broadening the scope of our conflict types remains an area of future investigation.

${ }^{18}$ Huntington (1996, p.159) provides an explicit map of the buffer between the 'Christian' and 'Muslim' civilizations. It is roughly defined by a North-South axis which effectively splits the European continent from Asia, running "along what are now the borders between Finland and Russia and the Baltic states (Estonia, Latvia, Lithuania) and Russia, through western Belarus, through Ukraine separating the Uniate west from the Orthodox east, through Romania between Transylvania with its Catholic Hungarian population and the rest of the country, and through former Yugoslavia along the border separating Slovenia and Croatia from the other republics. In the Balkans, of course, this line coincides with the historical division between the Austria-Hungarian and Ottoman empires."

In what follows, we shall abide by this demarkation.
} 
forced to convert with more frequency by societies which subscribed to majority religions in the buffer zones, thereby leading to forced conversion to the monotheistic religion or to a syncretized form of religion (sects) that were marginally tolerated by the dominant religion. Such dynamics would have produced more religious homogeneity in the buffer zones. On the other hand, buffer zones could have been areas with more religious porousness, especially if the more intense nature of ecclesiastical competition in the buffer zones enabled more proselytizing and voluntary conversions. In that case, religious diversity would have been higher in the buffer zones. For all these reasons, it is incumbent upon us to acknowledge - and, in what follows, explicitly control for - the special nature of the buffer zones in the dynamics of ethnic and religious fractionalization.

In terms of the patterns of warfare and conflict, we see that Austria, France, Germany, Italy, Poland, Russia, Spain and Turkey were the theaters of conflict most often. Adjusting for country size, some of those countries remain high on the list, although the incidence of violent conflicts in Germany, Russia and Turkey adjusted for their geographic size is relatively low. Of the 52 countries in the sample, predominantly eastern European and Balkan countries, such as Albania, Greece, Austria, Bulgaria, Turkey and Ukraine, saw the most Muslim on Christian conflicts. But in Spain and Russia too there were relatively more conflicts which pitted Muslim against Christian players. And in six of the countries in the sample, including France, Germany and Switzerland, there were violent confrontations between Protestants and Catholics. Although not shown, our data also cover four countries - Belarus, France, Portugal and Spain - where one or more pogroms took place between 1400 and 1900 CE. Figure 1 is replicated from Iyigun, Nunn and Qian (in progress); it shows the conflicts in our dataset by century and geographic location.

[Table 1 and Figure 1 about here.]

Now some salient descriptive data statistics. First, note that countries are more religiously fractionalized than they are ethnically or linguistically. At the same time, there is also a higher level of cross-country variance in religious fractionalization. There were close to 18.3 conflicts within each country in the sample over the 500-year interval between 1400 and $1900 \mathrm{CE}$. Among these conflicts, there were on average 3.3 violent 
confrontations per country that involved Muslim and Christian sides, about .73 which pitted Catholics against Protestants and .096 of Jewish pogroms per country. Catholic on Protestant conflicts lasted much longer on average than those between Muslims and Christians which in turn lasted much longer than Jewish pogroms and other types of violent confrontations. Conditional on the fact that there was at least one such type of confrontation within country borders over the interval between 1400 and $1900 \mathrm{CE}$, a typical Protestant versus Catholic conflict lasted more than 3.5 years, whereas Muslim on Christian conflicts lasted roughly three years and Jewish pogroms on average did not even last half a year.

Using our longer timespan covering the period between 1400 and $1900 \mathrm{CE}$, the average year of conflicts was 1644, with Muslim on Christian wars occurring on average around the year 1626 and Jewish pogroms being dated around the year $1500 \mathrm{CE}$. By contrast, when we restrict the time coverage to the two-century interval between 1400 and $1600 \mathrm{CE}$, those dates are respectively revised as 1512, 1547 and $1451 \mathrm{CE}$.

Finally, note that there is a positive but relatively low level of positive correlation between religious fractionalization and the two other fractionalization measures, although that between religious and linguistic fractionalization is the higher of the two measures. By contrast, the correlation between ethnic and linguistic fractionalization is still positive but much higher. Religious fractionalization exhibits a negative and relatively low correlation with Christian on Muslim conflicts, but it shows a positive and modest correlation with Protestant and Catholic wars and a low positive correlation with Jewish pogroms. The correlation of religious fractionalization with the duration of different kinds of conflict varies too, with the correlation of religious fractionalization and the duration of Muslim versus Christian conflicts being the only one which is slightly negative. As shown in the second panel of Table 2, the geographic correlations of the religious fractionalization measure confirm that the Balkans and Eastern Europe are highly fractionalized whereas the Middle East is not. In our final panel in Table 2, we document that all three measures of fractionalization rise with distance from the equator, although ethnic fractionalization does so by a much smaller magnitude. Countries in which a majority of the population is Christian (Muslim) are religiously more (less) fractionalized, reflecting in part the higher (lower) extent of denominational plurality 
within Christianity (Islam).

[Table 2 about here.]

\subsection{Main Results}

In our baseline estimates, we cover the period 1400 through to $1900 \mathrm{CE}$ and estimate the following regression equation:

$$
\begin{gathered}
\text { FRAC }_{i}=\lambda_{0}+\lambda_{1} \text { TOTALCONFLICTS } \\
\lambda_{2} \text { MUSLIMCHRISTIANWARS }+\lambda_{3} \text { PROTESTANTCATHOLICWARS } \\
+\lambda_{4} \text { POGROM }_{i}+\lambda_{5} \text { DURCONFLICTS } S_{i} \\
+\lambda_{6} \text { DURMUSLIMCHRIST } T_{i}+\lambda_{7} \text { DURPROTESTCATH } H_{i} \\
+\lambda_{8} D U R P O G R O M_{i}+\lambda_{9} X_{i}+\varepsilon_{i}
\end{gathered}
$$

where $F R A C_{i}$ is one of three alternative dependent variables constructed by Alesina et al. (2003); TOT ALCONFLICT $S_{i}$ is the total number of violent confrontations that occurred within country $i$ 's borders between $1400 \mathrm{CE}$ and $1900 \mathrm{CE}$; MUSLIMCHRISTI$A N W A R S_{i}$ is the count of violent confrontations between Muslims and Christians which took place in country $i$ over the relevant time span; PROTEST ANTCATHOLICW ARS is the count of violent conflicts between Catholics and Protestants that occurred in country $i$ between $1400 \mathrm{CE}$ to $1900 \mathrm{CE}$; POGROM $M_{i}$ is the number of Jewish pogroms which took place in country $i$ during the same period; and DURCONFLICTS $S_{i}$ DURMUS - LIMCHRIST, DURPROTESTCATH L DURPGROM $_{i}$ denote the average duration of the types of conflict we defined above, respectively. ${ }^{19}$

\footnotetext{
${ }^{19}$ For complete details of how the various fractionalization measures are defined and calculated, see Alesina et al. (2003).
} 
In our most parsimonious empirical specifications, the set of control variables $X_{i}$ includes nine geographic dummy variables, WESTERNEU, CENTRALEU, EASTERN - EU, NORTHERNEU, BALKANS, AFRICA, ASIA, MIDEAST and ISLAND. Note that, taken together, two of those geographic dummies, EASTERNEU and BAL - KANS, define what turned out to be the historical buffer zone between Christian and Muslim societies. In other more comprehensive estimates, we also include in $X_{i}$ the population level of $i$ in 1994, POPULATION; the distance from the equator of country $i$ 's capital, EQUATOR; a dummy for whether or not $i$ is landlocked, LANDLOCK; country $i$ 's land area in $\mathrm{km}^{2}, L A N D A R E A$; the population estimates for $1000 \mathrm{CE}$ and 1500 CE, POP 1000 and POP 1500, respectively; the distance of country $i$ 's capital from the three ecclesiastical centers of Rome, Jerusalem and Mecca, ROME, JERUSALEM, and $M E C C A$; dummies for whether a majority of the population was a Christian or Muslim majority in 1994, CHRISTIANMAJOR and MUSLIMAJOR; and the years during which each of the four types of conflict took place on average, Y RCONFLICT, YRMUSLIMCHRIST, Y RPROTESTCATH and YRPOGROM.

Table 3 displays results from four regressions that employ religious fractionalization as the dependent variable. ${ }^{20}$ Column (1) shows results from the most parsimonious of regressions, with controls only for geographic region as part of $X_{i}$. As mentioned earlier, certain areas of Europe tend to be more homogeneous than others, hence the addition of geographic dummies controls for regional differences. Column (2) adds a control for land area, $L A N D A R E A$, which is reported, though not significant, a dummy for whether the country is landlocked, $L A N D L O C K$, and current population, POPULATION, in case fractionalization is correlated with population size. ${ }^{21}$ Column (2) also adds variables for distance to the equator and a dummy for whether a country is landlocked. Column (3) builds on the specification in (2) with the additional variables of distance to major religious centers of Mecca, Rome and Jerusalem, as well as a dummies for whether the country had a Muslim or Christian majority in 1994, and its population in the years 1000

\footnotetext{
${ }^{20}$ In all results shown, we report the heteroskedasticity-corrected standard errors.

${ }^{21}$ It is important to control for country size to the extent that country formation is endogenous and causality runs from violent confrontations to country size, which in turn affects our measures of fractionalization. Put differently, to the extent that the impact of conflicts on fractionalization arises from endogenous country formation, controlling for $L A N D A R E A$ could help to limit omitted variable biases.
} 
and $1500 \mathrm{CE}$. Of these, only the religious majority coefficients are reported. ${ }^{22}$ Column (4) adds variables associated with the average year of the conflict both in general and by the types of religious conflict, although they are not reported. All in all, these additional control variables are highly correlated with duration and do not appear to have a large effect on magnitude or significance of the variables in question.

In all four regressions in Table 3, religious fractionalization depends negatively and statistically significantly on the frequency of Muslim on Christian wars and typically positively - though not significantly - on wars between Protestants and Catholics. These results buoy the thesis that the long-run incidence and patterns of religious conflicts - in this case, those between Muslims and Christians, in particular - did impact the contemporaneous extent of religious fractionalization within countries. The role of historical conflicts in influencing modern-era fractionalization is quite large. In the simplest regression in Table 3, for instance, one more violent incident in which Muslims fought against Christians is associated with close to five percent less religious fractionalization, or a generally more homogenous religious community some 400 years later. ${ }^{23}$ The result increases in magnitude as controls are introduced and remains statistically significant. Additionally, we see that the duration of Muslim versus Christian conflicts enters negatively, decreasing fractionalization by 6 to 9 percent depending on the specification, though reaching statistical significance only in column (2). The frequency of Jewish pogroms is also associated with increased religious fractionalization, although the magnitude and significance varies by specification. However, the duration of pogroms is associated with decreased fractionalization.

While these baseline results show a pattern that will remain at the fore the rest of the way, they also invite the question of why Muslim on Christian conflicts had an opposite impact than those between Protestants and Catholics or, for that matter, the incidence of Jewish pogroms in a region. There is no clear cut answer to this. A plausible conjecture is that the types of conflict in question also differ from one another in the extent to which the underlying sources of conflict have been mitigated or resolved in the

\footnotetext{
${ }^{22}$ The coefficients not shown typically are statistically insignificant, with occasionally alternating signs across the different empirical specifications.

${ }^{23}$ The coefficient of MUSLIMCHRISTIAN in the column (1) estimate of Table 3 is -.016 . Given that the average fractionalization rate is .369 in our sample, this corresponds to a 4.3 percent lower fractionalization rate due to one extra conflict between Muslims and Christians.
} 
course of time- however, superficially or fundamentally that may be.

In particular, the process through which the Protestant and Catholic Christian denominations came to terms with their underlying differences was arduous and prolonged. The seeds of this confrontation lay in centuries past and the 'heretical' movements of Lollardy, Huguenots and Hussites. The confrontation spanned more than 130 years between the official inauguration of the Reformation in 1517, ran through the 1555 Peace of Augsburg, when the Holy Roman Empire officially recognized the Lutheranism, culminated with the Treaty of Westphalia signed at the end of the Thirty Years War in 1648, which marked the official recognition of Protestantism by the Roman Catholic Church. When this fundamental ecclesiastical disagreement was eventually settled, religious pluralism within Christianity started to become the accepted European norm. Such acceptance and coexistence began to define, to some extent, the relationship between Christianity and Judaism too, especially in Europe, though this took until the end of the Second World War.

In contrast, one ought to bear in mind that the era that we are investigating coincides with a period when both Christianity and Islam had been established long ago, but the competition between them had once again intensified with the Ottomans' domination of eastern Europe in the 15th and 16th centuries and the Spanish Reconquista in 1492. And, as we alluded to in our introduction, the One God-One True Religion duality inherent in all three major monotheisms has historically been an important factor in sustaining violent encounters between Muslim and Christian societies. Hence, these differences may be at the core of why the different types of conflicts and violence influenced differently modern-day religious fractionalization across countries.

The fact that the duration of Jewish pogroms depressed religious fractionalization, whereas their incidence stimulated it is also puzzling. However, it is important to point out that the impact of duration is conditional on the incidence of pogroms and vice versa. Hence, what we are picking up might be the influence of a history of sustained suppression driving religious homogeneity. Moreover, it is also important to note that the fractionalization measures are self-reported. A country with a history of religious repression may also have encouraged Judaism to go underground by making it unacceptable 
to report being Jewish, thus leading to increased homogeneity. ${ }^{24}$ Pogroms that lasted longer might have exerted more influence or simply encouraged out-migration and thus increased homogeneity. ${ }^{25}$ On the flip side, pogroms could have invoked the same sort of mechanism as conflicts within Christian sects discussed above, magnifying internal differences and subsequently resulting in increased religious fractionalization.

Finally, it is worthwhile to remark that, with the exception of some of the geographic dummy variables that come in statistically significant, although not robustly to changes of empirical specification, only a few of the right-hand side variables, which we singled out above, have explanatory power. Despite this observation, the fit of the regressions, even of the baseline version, is quite high as indicated by the $R^{2}$ measures.

[Table 3 about here.]

Tables 4 and 5 employ the same specifications shown in the previous table but with ethnic and linguistic fractionalization, respectively, as the dependent variables. Though the direction of the effect of religious conflicts on fractionalization is generally maintained, the impact of the latter on ethnic and linguistic fractionalization is overwhelmingly insignificant statistically. This stands in stark contrast to the results we reported in Table 3. One exception is provided by the statistically significant and negative impact of the duration of Muslim on Christian wars on ethnic fragmentation in columns (1), (2) and the negative and significant role of pogroms on ethnic fractionalization in column (2) of Table 4. Interestingly, the coefficient on the frequency of total confrontations, TOT ALCONFLICTS, now enters negatively in five of the eight specifications in Tables 4 and 5 , with three of the five also being statistically significant. In particular, the

\footnotetext{
${ }^{24} \mathrm{As}$ it is well known, this was certainly the case in the Iberian peninsula after 1492, but sporadically even before that.

In fact, starting in the 9th century, the Spanish Reconquista began to take shape with the Christian kingdoms up north pushing the frontiers southward into Muslim-held lands. By mid-13th century, Christian kingdoms had regained back most of the peninsula. Although the adherents of the three Abrahamic traditions coexisted on the peninsula rather peacefully by medieval standards even after the Reconquista began, there were on occasion flare ups, such as the movement of the Cordoban Martyrs, a group of al-Andalus Christians "who provoked and achieved martyrdom at Muslim hands in the ninth-century Cordoba," (Constable, 2006, p. 307).

${ }^{25} \mathrm{~A}$ large number of the Sephardim resettled in the Ottoman Empire during the reign of Sultan Beyazid II (r. 1481-1512) who dispatched the Ottoman navy for their transfer. The number of Sephardic Jews who were resettled in various parts of the still-fledgling Ottoman empire - in particular, in Salonica, Avlona, Palestine and Istanbul — is estimated to have totaled 100,000 (Kumrular, 2008, p.24).
} 
dampening influence of TOT ALCONFLICT on ethnic fractionalization in column (1) of Table 4 and its similarly negative impact on linguistic fractionalization in columns (1) and (2) of Table 5 contrast with the insignificant role of conflicts generally in religious fractionalization.

As shown in Tables 4 and 5, little else provides an evidently strong predictor of either ethnic or linguistic fractionalization. As discussed above, our data reflect a higher degree of religious fractionalization than either ethnic or linguistic. Thus, the lower levels and variance of ethnic and linguistic fractionalization might in part account for our results not being as strong as those reported in Table 3. Still, the effects of our explanatory variables on ethnic fractionalization present slightly stronger and more uniform results over various specifications than linguistic fractionalization. This should again be viewed in light of the fact that our data reflect less linguistic fractionalization than ethnically. All in all, the weaker power of our set of right-hand side variables in explaining either ethnic or linguistic fractionalization vis-a-vis religious fractionalization is manifested in the fit of the specifications as summarized by the $R^{2}$ measures in Tables 4 and 5 .

[Tables 4 and 5 about here.]

\subsection{Alternative Specifications \& Robustness}

Now we can turn to issues of robustness and a discussion of various alternative specifications.

First and foremost, and as we alluded to in our introduction, there is rightly a question of causality. That is, whether or not the long-run history of ecclesiastical conflicts had a bearing on religious, ethnic and linguistic homogeneity, or whether our results are merely reflective of a reverse causality channel through which we are picking up the effects of persistent levels of fractionalization on the propensities of varies sorts of conflict. In this, we are encouraged by numerous factors already discussed herein, including the fact that, with very few exceptions, the European continent presented relatively low levels of fractionalization in the medieval period. Moreover, the addition of regional controls should account for outliers such as the Balkans and the Iberian Peninsula before 1492, which represented some of the geographies with above-average fractionalization. 
All the same, we decided to rerun our empirical tests using a three hundred-year time lag between our fractionalization observations and the conflict data. In particular, instead of tracking the patterns, types and attributes of violent confrontations over the half millennium between 1400 to $1900 \mathrm{CE}$, we generated an alternative variant of the conflict variables which was based on data covering the two centuries between 1400 and $1600 \mathrm{CE}$. This yielded 502 total conflicts in the 52 countries in our sample -instead of the 953 over the 500-year interval. ${ }^{26}$

Tables 6, 7, and 8 provide the results derived using this new sample but otherwise replicating the empirical specifications shown in Tables 3, 4 and 5, respectively. By incorporating a longer time lag examining only the period covering the two-century span between 1400 to $1600 \mathrm{CE}$, we see in Table 6 that the effect of wars on religious fractionalization are very much in line with - and in some cases, in fact, stronger - than using the entire period 1400 to $1900 \mathrm{CE}$. Not only are the $R^{2}$ measures comparable if not better than those shown in Table 3, but the three types of ecclesiastical conflict measures, MUSLIMCHRISTIAN, PROTESTCATHOLIC and POGROM, are statistically significant in nine out of 12 times and directionally always consistent with Table 3 results: ${ }^{27}$ Muslim on Christian confrontations that took place between the 15th and 17th centuries depressed the current-day religious fractionalization of countries, although only in the column (4) regression does the coefficient on MUSLIMCHRISTIAN attain significance at the 10 percent level. By contrast, the Protestant on Catholic conflicts or Jewish pogroms that took place four centuries ago or earlier raised religious fractionalization, entering the four specifications always positively and statistically significantly.

While other control variables are typically insignificant, the geographic dummies for the Middle East, eastern Europe and the Balkans in some specifications are significant. And in terms of the duration of conflicts we again have some evidence that longer religious conflicts - in this case, DURPOGROM only - typically reduced religious homogeneity. In terms of quantitative effects, the results we obtain with this longer-lag data are still stronger: in column (4) for instance, a ten percent higher incidence of Muslim

\footnotetext{
${ }^{26}$ We also examined our main findings using data for the period between 1400 and $1700 \mathrm{CE}$. Since those data yielded results that are analogous to the oned we discuss here, we have chosen not to report them.

${ }^{27}$ For contrast, consider that MUSLIMCHRISTIAN, PROTESTCATHOLIC and POGROM, are statistically significant in only five out of 12 specifications in Table 3.
} 
on Christian wars is associated with close to a ten percent decrease in religious fractionalization, the magnitude of which is larger than the range implied by the regressions covering the entire 1400 to $1900 \mathrm{CE}$ time period.

[Table 6 about here.]

In Tables 7 and 8 we report the estimates in which ethnic and linguistic fractionalization are defined as the dependent variables, respectively. The results using only the period 1400 to $1600 \mathrm{CE}$ exhibit similar tendencies to those where the entire period was in use. In particular, our conflict data aren't as powerful as they are in explaining ethnic or linguistic fractionalization as they are in religious fractionalization. However, the results shown in Tables 7 and 8 are still much stronger than those reported in Tables 4 and 5 . In particular, TOT ALCONFLICTS has a depressing effect in one specification with ethnic fractionalization as the dependent variable and it has such an effect in two regressions where linguistic fractionalization is the dependent variable. This is in clear contrast to the results with religious fractionalization, which do not yield any explanatory power to the overall level of conflicts in fractionalization. The one significant difference between the results shown in Tables 7 and 8 vis-a-vis those reported in 4 and 5 is that POGROM has a statistically significant, positive impact on ethnic and linguistic fractionalization in seven of the eight specifications, whereas DURPOGROM has a negative and statistically significant impact on ethnic and linguistic fractionalization in 6 of the eight regressions shown. This effect is in line with those on religious fractionalization reported in Tables 3 and 6 , but they are in strong contrast with those in Tables 4 and 5 where the impact of conflicts over the longer time horizon of 1400 to $1900 \mathrm{CE}$ on ethnic and linguistic fractionalization is shown to be typically insignificant. ${ }^{28}$

[Tables 7 and 8 about here.]

A four-century lag between measures of conflict and fractionalization provides us some comfort that we are distilling off any impact fractionalization could have on conflicts. Nonetheless, even a four century lag would not compensate for omitted variable

\footnotetext{
${ }^{28}$ Although none of the results discussed here control for it, we also ran our key regressions with the error terms being clustered on the basis of the nine geographic regions. Doing so weakened some of the coefficients on MUSLIMCHRISTIANWARS and made some coefficients statistically insignificant, but the qualitative nature of our results did not change radically.
} 
biases inherent in the results above. This is why we controlled for the dates of independence in some alternative estimates and substituted more or less aggregated geographic controls for countries in Europe in various other regressions. Neither of these alterations influenced the essence of our main findings. Furthermore, for an empirical work whose key explanatory data cover the medieval era, our $R^{2}$ measures are unusually high, exceeding .76 in some specifications where religious fractionalization is the dependent variable. This is another reason why omitted variable biases are probably not exerting a meaningful bias in the key results.

Of course, employing IV estimates could serve as a compelling alternative to lengthening our time lags or considering different sets of control variables. Here, we are somewhat handicapped due to the lack of viable instrumental variables: most available instruments for conflicts are plausible determinants of ethnic, religious or linguistic fractionalization too. However, the various measures of distance from Jerusalem, Rome and Mecca could serve as instruments for religious conflict, to the extent that (i) the historical patterns of ecclesiastical conflicts were shaped by proximity — or lack thereofto geographic regions that have been pivotal for Judaism, Christianity and Islam; and (ii) the spread and contractions of Judaism, Christianity and Islam historically were predominantly driven by conflicts instead of peaceful proselytizing, so as to make religious, ethnic and even linguistic fractionalization functions of ecclesiastical conflict but not distance to the ecclesiastically-important cities.

With this possibility in mind, we estimated a 3-stage least squares IV regression. In the first stage of our 3-stage least squares IV estimation, we regressed MUSLIM CHRISTIANWARS and PROTESTANTCATHOLICWARS on JERUSALEM, $R O M E, M E C C A$, the two- and three-way interactions among those three distance measures as well as the dummies EASTERNEU and BALKANS, which together define the buffer zone between eastern Europe and the near East. In the second stage, we then estimated the impact of MUSLIMCHRISTIANWARS and PROTESTANTCATH - OLICWARS on fractionalization. And in the final stage, we regressed average economic growth rates over the period between 1970 and 2002 on fractionalization. ${ }^{29}$

\footnotetext{
${ }^{29}$ Another limitation of this strategy is due to limited sample size: many of the east European, near Asian and Balkan countries in our sample became independent of the Iron Curtain in the early-1990s. Hence, economic growth data averaged over a relatively meaningful (read: long enough) time interval is
} 
Our results are summarized in Tables 9.A through 9.C. As shown in the final panel of 9.C, all the distance measures help predict the propensity of conflict between Christians and Muslims. As summarized in 9.B, PROTEST ANTCATHOLICWARS in particular, but MUSLIMCHRISTIANWARS too, have predictive power in estimating religious and ethnic fractionalization. And as Table 9.A shows, religious fractionalization, as instrumented with our conflict variables cum ecclesiastical distance measures, exerts a statistically significant and negative effect in two regressions, attaining a p-value of 11 percent in the third. This seems to be the case with ethnic fractionalization too, with the coefficient estimate for it generating a statistically significant negative impact in the two estimates ethnic fractionalization is included as a determinant of economic growth. As shown in the final column, however, linguistic fractionalization yields a statistically insignificant effect when all fractionalization measures are included, although all three variables yield negative coefficients. ${ }^{30}$ On the one hand, these results verify that ethnic fractionalization is detrimental to long-run economic growth. On the other hand, they stand in contrast to those in the existing literature that have either not been able to establish a link between religious fractionalization and economic growth or found religious fractionalization having a positive effect on it.

[Tables 9.A through 9.C about here.]

As a final line of inquiry, what can we say about the role of the longer-term history of violent conflicts on development indirectly through their impact on institutions? As we alluded to in our introduction, there is a strand in the empirical development literature which has shown that ethnic and linguistic fractionalization has detrimental available for only 30 of the 52 countries in the original sample.

${ }^{30}$ The first-stage $F$-statistics for MUSLIMCHRISTIANW ARS are high enough that we have no reason to suspect our ecclesiastical distance measures to be weak instruments for Muslim versus Christian wars. The same is not true for PROTESTANTCATHOLICWARS, with its first-stage $F$-statistics being less than unity in all three estimates.

In any case, to verift the strength of our instruments, we experimented with conditional likelihood ratio $(C L R)$ confidence intervals for two separate $2 S L S$ specifications in which MUSLIMCHRISTIANWARS and PROTESTANTCATHOLICWARS were, in turn, instrumented for in the first stage and religious fractionalization was regressed on either of the two conflict measures in the second. Those tests yielded bounded and directionally consistent (i.e., negative) intervals for Muslim on Christian wars. Moreover, the Sargan test p-values indicated that our instruments satisfy the over-identifying restrictions. 
effects on economic growth and development, but only indirectly. Since our results thus far illustrated that the history of religious conflicts especially had effects on modernera cross-country differences in fractionalization, we believe it is incumbent upon us to examine if conflicts alone can help to explain differences in institutional quality.

Table 10 reports our findings with countries' polity scores as measured with the POLITY data is the dependent variable, which is regressed on the standard explanatory variables that we employed as the determinants of fractionalization. As shown, we pickup a strong impact of the history of conflicts over the period between 1400 to $1900 \mathrm{CE}$ on the quality of polities in 1994. ${ }^{31}$ Specifically, whereas the incidence of Muslim on Christian conflicts had a dampening effect on religious fractionalization, it is shown to have had positive and, in three of the four specifications, statistically significant effects on polities. In contrast, the incidence of pogroms yields negative and in two of the four regressions statistically significant effects on polity scores. The duration of the three types of religious violence typically produced statistically significant effects on polities, although the directional impact of conflict duration was ambiguous, especially in the cases of DURPROTESTCATH and DURPOGROM. In the next section, we will have more to say on this topic.

[Table 10 about here.]

\section{Discussion}

The results above show that the long-term history of violent conflicts, in general, and those of a religious nature, in particular, had a bearing on the contemporary differences of cross-country religious fractionalization. They suggest that violent conflicts and religious confrontations influenced ethnic and linguistic fractionalization too, although to a much lesser extent. Furthermore, religious conflicts seem to have exerted statistically significant - in some cases adverse but in others favorable - effects on institutional quality, as measured by countries' polity scores.

The existing literature on the subject has long established a generally robust adverse impact of fractionalization on measures of institutional quality. In fact, although

\footnotetext{
${ }^{31}$ Running the same regressions with the 1400 to $1600 \mathrm{CE}$ conflict data and the four century lag instead of one century produced very similar, if not stronger, results. All results discussed but not shown are, of course, available upon request.
} 
we have chosen not to present them here for the sake of brevity, estimating the analogs of the regressions in Table 10, but replacing all of the various conflict measures which we controlled for thus far with the three alternative fractionalization measures, we too were able to verify the statistically significant, detrimental effects of ethnic and linguistic fractionalization, in particular, on polity scores.

Taken together with the results we have presented thus far, these findings raise an intriguing question: If fractionalization is influenced in part by violent conflicts and religious confrontations, which, together with fractionalization, then have a bearing on the cross-country differences in the quality of polities, do violence and religious confrontations have a direct role in POLITY or do their effects filter only indirectly through fractionalization?

Given the data at hand, this is a question to which we can provide some answers. In Table 11 we summarize some of our related findings. ${ }^{32}$ Interestingly, when we include the three measures of fractionalization along with the standard list of conflict variables we relied on in the previous tables, we find that neither religious nor linguistic fractionalization impacts cross-country differences in institutional quality, as proxied by polity scores. But depending on the specification, some conflict measures continue to exert statistically significant effects on POLITY. For instance, the frequency of Muslim on Christian violent conflicts has positive coefficients in all four specifications and it is statistically significant in column (2) at the 5 percent level. Moreover, although its coefficient estimates aren't significant in the other regressions, the estimate of the MUSLIMCHRISTIAN coefficient yield a p-value of 16 in columns (3). These results are perfectly in line with - albeit somewhat weaker — than those reported in Table $10 .{ }^{33}$

[Table 11 about here.]

There are at least two not necessarily mutually exclusive observations we can make on this basis. One, the very long-run histories of conflict, in general, and those that are of

\footnotetext{
${ }^{32}$ These results were produced using conflict data covering the period between 1400 and $1900 \mathrm{CE}$, but an exercise in which we used data for the 1400 to $1600 \mathrm{CE}$ interval instead generated qualitatively quite similar findings. Hence, we chose not to report them here.

${ }^{33}$ To see if violent conflicts impacted a narrower measure of polity, we ran regressions similar to the one we discuss here, using the democracy index score as the dependent variable instead. Doing so we generally found conflicts to have insignificant effects on democracy.
} 
an ecclesiastical nature, in particular, had some long-lasting and direct effects on crosscountry differences in institutional quality. Two, the long-standing standard arguments as well as findings that fractionalization impacts institutions seem to be sensitive to whether or not the direct effects of the history of violence on institutions are controlled for. As all our earlier results attest, however, this is not tantamount to concluding that various types of fractionalization have no impact on the evolution of institutions, although they do indeed suggest that fractionalization is endogenous.

If conflicts and religiously motivated or sustained confrontations do help to explain the cross-country variations in the quality of polities and the extent of fractionalization, then what factors influence the historical patterns of conflict? Besides some of the literature referenced above that puts a premium on cultural differences as a determinant of violent conflicts historically as well as the $3 S L S I V$ estimates we reviewed above, some other influential contributions, such as Tilly (1992), have at least implicitly emphasized the role of technological change and geography. This is an area of ongoing investigation which we pursue in Iyigun, Nunn and Qian (in progress).

Next, in interpreting our findings, it is important to bear in mind that our data cover the history of a limited geographic area extending from Europe, the Middle East, the near East to the Arabian peninsula and North Africa; they cover neither sub-Saharan Africa, Far East Asia nor the Americas. Thus, while our geographic coverage pertains to the regions of the world in which major ecclesiastical dynamics and interactions unfolded historically, one would have to be cautious in the external validity of these conclusions both in time and space.

We can finally wrap the paper up with the implications of our findings for the role of ethno-religious fractionalization and divisions in civil wars and internal conflict. We have shown that the long-run historical record and patterns of violent conflict influenced the current levels of ethnic and religious fractionalization. We have, in fact, identified that the modern-era levels of religious fractionalization in particular depend on the type of conflicts that occurred in a given region. On that basis, then, it is possible that the contemporary levels of fractionalization are low due to the fact that the underlying historical sources of conflict have still not been resolved. Or, conversely, fractionalization might be high now precisely because the sources of conflict have been settled over the 
course of history.

\section{Conclusion}

A sizable literature has shown that fractionalization influences economic development and growth indirectly, without yielding any evidence that the standard measures of ethnic or religious fractionalization have a quantitatively and statistically significant effect on violent conflict within countries.

In this paper, we examined the long-run determinants of contemporary fractionalization across countries along the ethnic, linguistic and religious dimensions. Relying on some novel data that cover 953 violent confrontations which took place in 52 countries over the period between 1400 and $1900 \mathrm{CE}$, we identified that the frequencies and types of conflict influenced contemporary levels of religious and to some extent ethnic fractionalization too. Specifically, we have demonstrated that the frequency of Muslim on Christian wars within a country's borders is a statistically significant and positive predictor of its current levels of religious homogeneity. By contrast, Protestant and Catholic confrontations within each country between the 15th and 19th centuries - and to some extent the incidence of Jewish pogroms too-produced more religious fractionalization today. And the longer were the duration of all such conflicts and violence, the less fractionalized countries are now. We have also established that these results are robust to the inclusion of various control variables.

In sum, the contemporary cross-country variations in religious heterogeneity reflect the history and type of ecclesiastical conflicts within countries. Those geographies where clashes took place more often and with a longer duration between Muslim and Christian 'civilizations' are likely to be the areas that are more homogenous today. Whereas the areas with a more frequent history of conflicts within the Judeo-Christian or Muslim 'civilizations' are more likely to be more heterogenous and fractionalized now. It is this sort of endogeneity that would render the relationship between fractionalization and the propensity of internal conflict statistically insignificant. Whether or not Huntington's thesis is an accurate description of the future will continue to be debated and fiercely contested. All the same, our findings show that the demographic structure of countries in Europe, the Middle East and North Africa do reflect the effects of a multitude of ecclesiastical and cultural clashes that occurred throughout the course of history. 
Finally, once we accounted for the endogeneity of fractionalization with respect to ecclesiastical conflicts, we found that religious fractionalization, if anything, negatively effects on economic growth. 


\section{References}

Abramitzky, R. (2008). "The Limits of Equality: Insights from the Israeli Kibbutz," Quarterly Journal of Economics, 123:3, August, 1111-59.

Alesina, A., R. Baqir and W. Easterly. (1999). "Public Goods and Ethnic Divisions," Quarterly Journal of Economics, 114 (4), November, 1243-84.

Alesina, A., A. Devleeschauwer, W. Easterly, S. Kurlat and R. Wacziarg. (2003). "Fractionalization," Journal of Economic Growth, 8, 155-94.

Alesina, A. and E. Spolaore. (2007). "International Conflict, Defense Spending and the Size of Countries," European Economic Review.

Barbieri, K.(1996). "Economic Interdependence: A Path to Peace or a Source of Interstate Conflict?" Journal of Peace Research, 33(1), 29-49.

Barbieri, K. and G. Schneider. (1999), "Globalization and Peace: Assessing New Directions in the Study of Trade and Conflict", Journal of Peace Research, 36(4), 387404.

Barro, R. and R. McCleary. (2003). "Religion and Economic Growth," American Sociological Review, October.

Barro, R. and R. McCleary. (2005). "Which Countries Have State Religions?," Quarterly Journal of Economics, November.

Becker, O. S. and L. Woessmann. (2009). "Was Weber Wrong?: A Human Capital Theory of Protestant Economic History," Quarterly Journal of Economics, forthcoming.

Berman, E. (2000). "Sect, Subsidy and Sacrifice: An Economist's View of Orthodox Jews," Quarterly Journal of Economics, August.

Botticini, M. and Z. Eckstein. (2005). "Jewish Occupational Selection: Education, Restrictions, or Minorities?," Journal of Economic History, 65:4, December.

Botticini, M. and Z. Eckstein. (2007). "From Farmers to Merchants, Voluntary Conversions and Diaspora: A Human Capital Interpretation of Jewish History," Journal of the European Economic Association, no. 5, September, 885-926.

Brecke, P. (1999). "Violent Conflicts 1400 A.D. to the Present in Different Regions of the World," 1999 Meeting of the Peace Science Society, unpublished manuscript.

Brecke, P. (in progress). "The Conflict Dataset: 1400 A.D. - Present," Georgia Institute of Technology. 
Campos, N, and V. S. Kuzeyev. (2007). "On the Dynamics of Ethnic Fractionalization," American Journal of Political Science, 51 (3), July, 620-39.

Canning, D. and M. Fay. (1993). "The Effects of Transportation Networks on Economic Growth," Columbia University, unpublished manuscript.

Caselli, F. and J. Coleman. (2006). "On the Theory of Ethnic Conflict," London School of Economics, unpublished manuscript.

Cioffi-Revilla, C. (1996). "Origins and Evolution of War and Politics," International Studies Quarterly, 40 (1), March, 1-22.

Clingingsmith, D., A. I. Kwaja, and M. Kremer. (forthcoming). Estimating the Impact of the Hajj: Religion and Tolerance in Islam's Global Gathering," Quarerly Journal of Economics.

Collier, P. and A. Hoeffler. (2005). "Coup Traps: Why does Africa have so many Coups d'Etat?," Department of Economics, University of Oxford, unpublished manuscript.

Collier, P. and A. Hoeffler. (2007). "Civil War," in the Handbook of Defense Economics 2, eds. Todd Sandler and Keith Hartley, April.

Constable, O. R. (2006). "Judaism, Christanity and Islam in Spain from the Eighth to the Fifteenth Centuries," in Religious Fondations of Western Civilization: Judaism, Christianity and Islam, in J. Neusner, ed., (Nashville, TN: Abingdon Press).

Easterly, W. and R. Levine. (1997). "Africa's Growth Tragedy: Policies and Ethnic Divisions," Quarterly Journal of Economics, 111 (4), November, 1203-50.

Ekelund, R., R. D. Tollison, G. M. Anderson, R. F. Hebert and A. B. Davidson. (1996). Sacred Trust: The Medieval Church as an Economic Firm, (New York, NY: Oxford University Press).

Ekelund, R., R. F. Hebert, and R. Tollison. (2002). "An Economic Analysis of the Protestant Reformation," Journal of Political Economy, June.

Emmanuel, A. (1972). Unequal Exchange: A Study of the Imperialism of Trade, (New York \& London: Monthly Review Press).

Fearon, J. and D. Laitin. (2003) "Ethnicity, Insurgency, and Civil War," American Political Science Review, 97:75-90.

Fernandez, R., A. Fogli and C. Olivetti. (2004). "Mothers and Sons: Preference Formation and Female Labor Force Dynamics," Quarterly Journal of Economics, 119 (4), 1249-1299, 2004. 
Fernandez, R. (2007). "Culture and Economics," in the New Palgrave Dictionary of Economics, 2nd edition, edited by Steven N. Durlauf and Lawrence E. Blume, Palgrave Macmillan (Basingstoke and New York).

Glaeser, E. L., and B. I. Sacerdote. (2002). "Education and Religion." Harvard University, unpublished manuscript.

Glaeser, E. L., R. La Porta, F. Lopez-de-Silanes, and A.Shleifer. (2004). "Do Institutions Cause Growth?" Journal of Economic Growth 9 (3): 271-303.

Glaeser, E. L. (2005) "The Political Economy of Hatred," Quarterly Journal of Economics, 120 (1), January, 45-86.

Greif, A. (1993). "Contract Enforceability and Economic Institutions in Early Trade: The Maghribi Traders' Coalition," American Economic Review, 83 (3), June, pp. 525-48.

Greif, A. (1994). "Cultural Beliefs and the Organization of Society: A Historical and Theoretical Reflection on Collectivist and Individualist Societies," Journal of Political Economy, 102 (5), October, pp. 912-50.

Greif, A. (2006). Institutions: Theory and History, (Cambridge: Cambridge University Press).

Grossman, H. I. (1994). "Production, Appropriation, and Land Reform," American Economic Review, 84(3), June, 705-12.

Grossman, H. I. and M. Kim. (1995). "Swords or Plowshares? A Theory of the Security of Claims to Property," Journal of Political Economy, 103(6), December, 12751288.

Grossman, H. I. and M. Iyigun. (1995)."The Profitability of Colonial Investment," Economics \& Politics, 7:3, November, 229-24.

Grossman, H. I. and M. Iyigun. (1997). "Population Increase and the End of Colonialism," Economica, 64(3), August, 483-493.

Guiso, L., P. Sapienza, and L. Zingales. (2003). "People's Opium? Religion and Economic Attitudes." Journal of Monetary Economics, 50 (1), 225-82.

Guiso, L., P. Sapienza, and L. Zingales. (2006). "Does Culture Affect Economic Outcomes?" Journal of Economic Perspectives, Spring, 20 (2), 23-48.

Haavelmo, T. (1968). A Study in the Theory of Economic Evolution, (Amsterdam: North-Holland). 
Hafer, C. (2006). "On the Origins of Property Rights: Conflict and Production in the State of Nature," Review of Economic Studies, January, 73 (1) 119- 43.

Hirshleifer, J. (1991). "The Paradox of Power," Economics \& Politics, 3:3, November, 177-200.

Huntington, S. P., (1993). "The Clash of Civilizations?," Foreign Affairs, Council on Foreign Relations, Summer issue.

Huntington, S. P., (1996). The Clash of Civilizations and the Remaking of World Order, (New York, NY: Simon \& Schuster).

Iannaccone, L. R. (1992). "Sacrifices and Stigma: Reducing the Free-Riding in Cults, Communes and Other Collectives." Journal of Political Economy 100 (2), April, 271—91.

Inglehart, R and W.E. Baker. (2000). "Modernization, Cultural Change, and the Persistence of Traditional Values," American Sociological Review, 65:19- 51.

Iyigun, M. (2007). "Monotheism (From a Sociopolitical and Economic Perspective)," IZA Working Paper No. 3116, October.

Iyigun, M. (2008a). "Luther and Suleyman," Quarterly Journal of Economics, 123 (4), November, 1465-94.

Iyigun, M. (2008b). "Lessons from the Ottoman Harem (On Ethnicity, Religion and Conflict)," IZA Working Paper No: 3556, July.

Iyigun, M. (forthcoming). Tales of Faith in Socioeconomic Progress, (Chicago, IL: The University of Chicago Press), book manuscript in progress.

Iyigun, M., N. Nunn and N. Qian (in progress). "Testing Tilly: Evidence from 1400-1945 CE Europe," University of Colorado, mimeo.

Jha, S. (2008). "Trade, Institutions and Religious Tolerance: Evidence from India," Stanford Business School, unpublished manuscript.

Knack, S. and P. Keefer. (1995). "Institutions and Economic Performance: CrossCountry Tests Using Alternative Institutional Measures," Economics and Politics 7(3):207227 (1995).

Kumrular, Ö. (2008). Türk Korkusu: Avrupa'da Türk Düşmanliğinin Kökeni, (İstanbul, Türkiye: Doğan Kitap).

Kuran, T. (2004a). "Why the Middle East Is Economically Underdeveloped: Historical Mechanisms of Institutional Stagnation," Journal of Economic Perspectives, 18, Summer, 71-90. 
Kuran, T. (2004b). "The Economic Ascent of the Middle East's Religious Minorities: The Role of Islamic Legal Pluralism," Journal of Legal Studies, 33, June, 2003, 475-515.

Kuran, T. (2005). "The Logic of Financial Westernization in the Middle East," Journal of Economic Behavior and Organization, 56 (April 2005): 593-615.

La Porta, R., F. Lopez de Silanes, A. Shleifer, and R. W. Vishny. (1999). "The Quality of Government," Journal of Law, Economics and Organization, 15 (1), 222-79.

Landes, D. (1998). The Wealth and Poverty of Nations, (New York, NY: W. W. Norton \& Co.).

Lee, J. and J. H. Pyun. (2008). "Does Trade Integration Contribute to Peace?," University of California, Davis, unpublished manuscript.

Levy, J. S. (1983). War in the Modern Great Power System, 1495 - 1975, (Lexington, KY: The University Press of Kentucky).

Lewis, L. D. (2008). God's Crucible: Islam and the Making of Europe, 570-1215, (New York, NY: W. W. Norton).

MacCulloch, D. (2003). The Reformation: A History, (New York, NY: Viking).

Mauro, P. (1995). "Corruption and Growth," Quarterly Journal of Economics, 110 (3), August, 681-712.

McEvedy C. and R. Jones. (1978) Atlas of World Population History. Facts on File, New York.

McNeill, W. (1984). The Pursuit of Power : Technology, Armed Force, and Society since A.D. 1000, (Chicago, IL: University of Chicago Press).

Miguel, E, S. Satyanath and E. Sergenti. (2004), "Economic Shocks and Civil Conflict: An Instrumental Variables Approach," Journal of Political Economy, 112: 725-753.

Moore, R. I. (1994). The Origins of European Dissent, originally published by Allen Lane, 1985, (Toronto, ON: University of Toronto Press).

Polachek, S. (1980), "Conflict and Trade", Journal of Conflict Resolution, 24 (1), 57-78.

Polachek, S., J. Robst and Y-C. Chang. (1999), "Liberalism and Interdependence: Extending the Trade-Conflict Model", Journal of Peace Research, 36 (4), 405-422.

Ray, D. (2005). "Polarization and Conflict," BP Lecture, London School of Economics, New York University, mimeo, May. 
Richardson, L. F. (1960). Statistics of Deadly Quarrels, (Pittsburgh, PA: The Boxwood Press).

Shaw, S. (1976). History of the Ottoman Empire and Modern Turkey, Vol. 1, (Cambridge: Cambridge University Press).

Skaperdas, S. (1992). "Cooperation, Conflict, and Power in the Absence of Property Rights," American Economic Review, September, 82, 720-39.

Skaperdas, S. (2005). "The Market for Protection and the Origin of the State," University of California at Irvine, unpublished manuscript, May.

Temin, P. (1997). "Is it Kosher to Talk about Culture?" Journal of Economic History, 57 (2), June, 267-87.

Tilly, C. (1992). Coercion, Capital and European States: AD 990 - 1992 (Studies in Social Discontinuity), (New York, NY: Blackwell Publishers).

Wilkinson, D. (1980). Deadly Quarrels: Lewis F. Richardson and the Statistical Study of War, (Berkeley, CA: University of California Press).

Woods, F. A. and A. Baltzly. (1915). Is War Diminishing? A Study of the Prevalence of War in Europe from 1450 to the Present Day, (Boston, MA: Houghton Mifflin Co.). 
Table 1: Wars \& Religious Fractionalization by Country \& Region

\begin{tabular}{|c|c|c|c|c|c|c|}
\hline & Country & $\begin{array}{c}\text { Relig. Fr } \\
(1)\end{array}$ & $\begin{array}{c}\text { Total } \\
(2)\end{array}$ & $\begin{array}{c}\text { Musl/Chris } \\
\text { (3) }\end{array}$ & $\begin{array}{c}\text { Pro/Cath } \\
(4)\end{array}$ & $\begin{array}{c}\text { Region } \\
(5)\end{array}$ \\
\hline 1 & Afghanistan & .2717 & 2 & 0 & 0 & Asia \\
\hline 2 & Albania & .4719 & 8 & 8 & 0 & Balkans \\
\hline 3 & Algeria & .0091 & 6 & 5 & 0 & N. Africa \\
\hline 4 & Armenia & .4576 & 2 & 2 & 0 & Asia \\
\hline 5 & Austria & .4146 & 32 & 8 & 0 & East EU \\
\hline 6 & Azarbeijan & .4899 & 2 & 1 & 0 & Asia \\
\hline 7 & Belarus & .6116 & 4 & 0 & 0 & East EU \\
\hline 8 & Belgium & .2127 & 16 & 0 & 0 & West EU \\
\hline 9 & Bosnia \& Her & .6851 & 10 & 6 & 0 & Balkans \\
\hline 10 & Bulgaria & .5965 & 8 & 6 & 0 & Balkans \\
\hline 11 & Croatia & .4447 & 7 & 3 & 0 & Balkans \\
\hline 12 & Cyprus & .3962 & 3 & 1 & 0 & M. East \\
\hline 13 & Czech Rep. & .6591 & 16 & 1 & 4 & East EU \\
\hline 14 & Denmark & .2333 & 12 & 0 & 0 & North EU \\
\hline 15 & Egypt & .1979 & 7 & 1 & 0 & N. Africa \\
\hline 16 & Estonia & .4895 & 5 & 0 & 0 & North EU \\
\hline 17 & Finland & .2531 & 3 & 0 & 0 & North EU \\
\hline 18 & France & .4029 & 97 & 0 & 14 & West EU \\
\hline 19 & Gaza Strip & .0342 & 1 & 0 & 0 & M. East \\
\hline 20 & Georgia & .6543 & 9 & 1 & 0 & Asia \\
\hline 21 & Germany & .6571 & 40 & 0 & 7 & Central EU \\
\hline 22 & Greece & .1530 & 29 & 26 & 0 & Balkans \\
\hline 23 & Hungary & .5244 & 12 & 3 & 0 & East EU \\
\hline 24 & Iran & .1152 & 16 & 3 & 0 & M. East \\
\hline 25 & Iraq & .4844 & 5 & 0 & 0 & M. East \\
\hline 26 & Ireland & .1550 & 16 & 0 & 6 & North EU \\
\hline 27 & Israel & .3469 & 1 & 1 & 0 & M. East \\
\hline 28 & Italy & .3027 & 93 & 1 & 0 & Central EU \\
\hline 29 & Latvia & .5556 & 3 & 0 & 0 & North EU \\
\hline 30 & Lebanon & .7886 & 1 & 0 & 0 & M. East \\
\hline 31 & Libya & .0570 & 2 & 2 & 0 & N. Africa \\
\hline 32 & Lithuania & .4141 & 6 & 0 & 0 & North EU \\
\hline
\end{tabular}


Table 1: (continued)

\begin{tabular}{|l|l|c|c|c|c|c|}
\hline Country & $\begin{array}{c}\text { Relig. Fr } \\
(1)\end{array}$ & $\begin{array}{c}\text { Total } \\
(2)\end{array}$ & $\begin{array}{c}\text { Musl/Chris } \\
(3)\end{array}$ & $\begin{array}{c}\text { Pro/Cath } \\
(4)\end{array}$ & $\begin{array}{c}\text { Region } \\
(5)\end{array}$ \\
\hline 33 & Luxembourg & .0911 & 1 & 0 & 0 & Central EU \\
\hline 34 & Malta & .1223 & 3 & 3 & 0 & Central EU \\
\hline 35 & Moldova & .5603 & 4 & 4 & 0 & East EU \\
\hline 36 & Netherlands & .7222 & 16 & 0 & 0 & West EU \\
\hline 37 & Oman & .4322 & 8 & 4 & 0 & M. East \\
\hline 38 & Poland & .1712 & 48 & 7 & 0 & East EU \\
\hline 39 & Portugal & .1438 & 19 & 0 & 0 & West EU \\
\hline 40 & Romania & .2373 & 24 & 15 & 0 & Balkans \\
\hline 41 & Russia & .4398 & 92 & 25 & 0 & East EU \\
\hline 42 & Saudi Ara & .1270 & 5 & 1 & 0 & M. East \\
\hline 43 & Slovakia & .5655 & 6 & 1 & 0 & East EU \\
\hline 44 & Spain & .4514 & 54 & 7 & 1 & West EU \\
\hline 45 & Sweden & .2342 & 28 & 0 & 3 & Central EU \\
\hline 46 & Switzerland & .6083 & 23 & 0 & 0 & M. East \\
\hline 47 & Syria & .4310 & 9 & 0 & 0 & N. Africa \\
\hline 48 & Tunisia & .0104 & 3 & 2 & 0 & M. East \\
\hline 49 & Turkey & .0049 & 44 & 11 & 0 & East EU \\
\hline 50 & Ukraine & .6157 & 23 & 13 & 3 & North EU \\
\hline 51 & United Kgm & .6944 & 64 & 0 & 0 & M. East \\
\hline 52 & Yemen & .0023 & 5 & 2 & 0 & 0 \\
\hline
\end{tabular}

Source: Religious fractionalization data, column (1) are from Alesina et al. (2003). The total number of violent conflicts, Muslim versus Christian and Protestant-Catholic confrontations reported in columns (2), (3) and (4),respectively are from Brecke (1999). 
Figure 1: Conflitcs by Century and Country

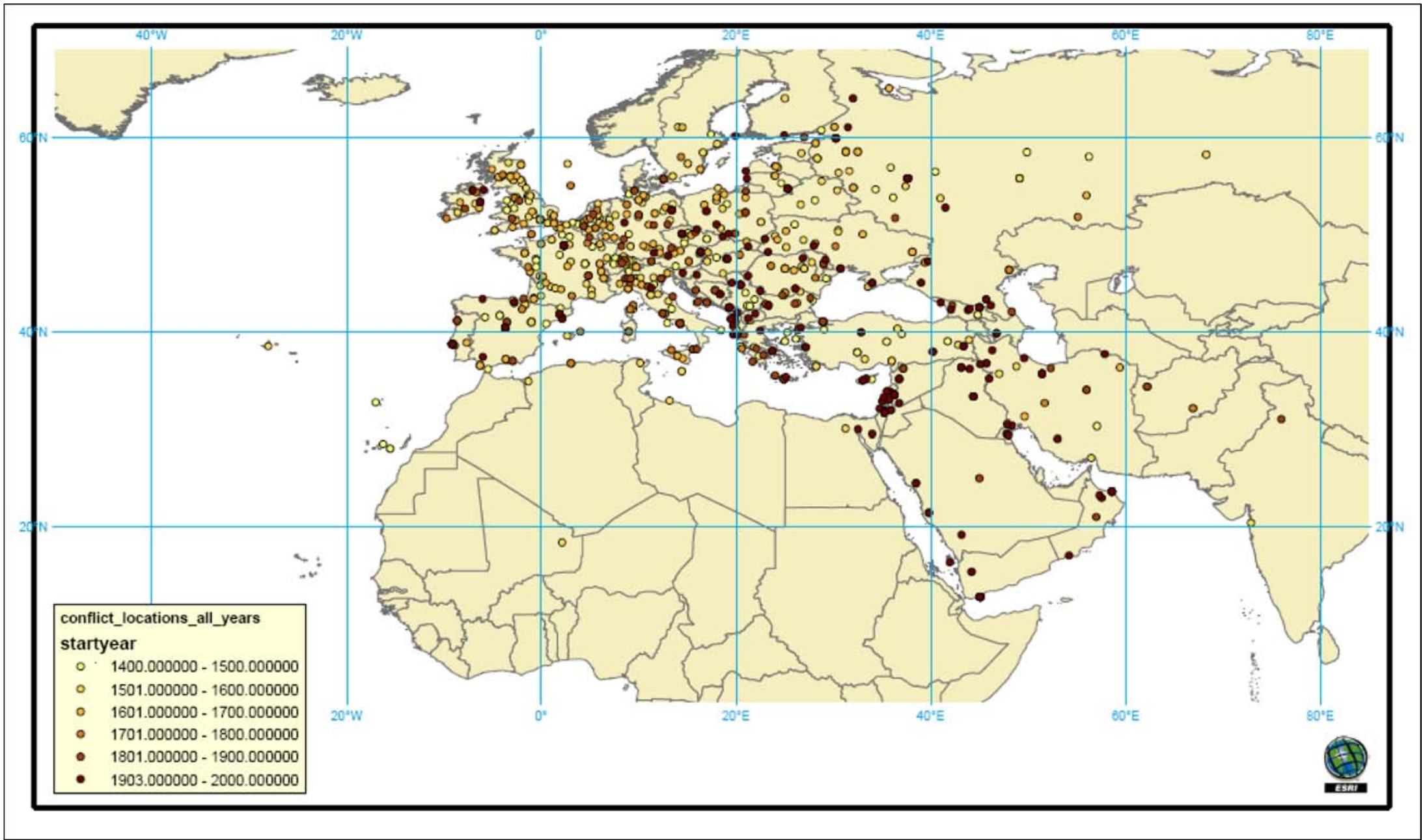

Source: Iyigun, Nunn and Qian (in progress). 
Table 2: Descriptive Statistics and the Correlation Matrix

\begin{tabular}{|c|c|c|c|c|c|c|c|c|c|c|c|}
\hline \multicolumn{3}{|c|}{$1400 \mathrm{CE}-1900 \mathrm{CE}$} & \multicolumn{9}{|c|}{ The Correlation Matrix } \\
\hline$n=52$ & Mean & St. Dev. & $R E L I G$ & $E T H N$ & $L I N G$ & $A V G C$ & $M S C H R$ & $C A T P R$ & $P O G$ & $D U R M C$ & $D U R C P$ \\
\hline RELIGFRAC & .369 & .222 & 1 & $\ldots$ & $\ldots$ & $\ldots$ & $\ldots$ & $\ldots$ & $\ldots$ & $\ldots$ & $\ldots$ \\
\hline ETHNOFRAC & .304 & .204 & .083 & 1 & $\ldots$ & $\ldots$ & $\ldots$ & $\ldots$ & $\ldots$ & $\ldots$ & $\ldots$ \\
\hline$A V G C O N F L$ & 18.3 & 23.8 & .020 & -.275 & -.234 & 1 & $\ldots$ & $\ldots$ & $\ldots$ & $\ldots$ & $\ldots$ \\
\hline$M U S C H R C O$ & 3.35 & 5.69 & -.128 & -.031 & -.128 & .356 & 1 & $\ldots$ & $\ldots$ & $\ldots$ & $\ldots$ \\
\hline CATPROCO & .731 & 2.38 & .133 & -.203 & -.170 & .478 & -.185 & 1 & $\ldots$ & $\ldots$ & $\ldots$ \\
\hline$D U R M U S C H$ & 1.73 & 2.18 & -.124 & .003 & -.148 & -.169 & .299 & -.231 & -.185 & 1 & $\ldots$ \\
\hline$D U R C A T P R O$ & .478 & 1.93 & .230 & -.093 & -.066 & .120 & -.131 & .496 & -.022 & -.093 & 1 \\
\hline DURPOGRO & .025 & .140 & .142 & -.012 & .107 & -.022 & -.093 & .024 & .499 & -.146 & -.035 \\
\hline
\end{tabular}

\begin{tabular}{|c|c|c|c|c|c|c|c|c|c|c|c|}
\hline \multicolumn{3}{|c|}{$1400 \mathrm{CE}-1900 \mathrm{CE}$} & \multicolumn{9}{|c|}{ The Correlation Matrix } \\
\hline$n=52$ & Mean & St. Dev. & $R E L G$ & $E T H N$ & $L I N G$ & $Y R C O N$ & $Y R M S C H$ & $Y R C T P R$ & $Y R P O G$ & $M E$ & $B A L K$ \\
\hline RELFRAC & .369 & .222 & 1 & $\ldots$ & $\ldots$ & $\ldots$ & $\ldots$ & $\ldots$ & $\ldots$ & $\ldots$ & $\ldots$ \\
\hline$E T H N F R A C$ & .304 & .204 & .083 & 1 & $\ldots$ & $\ldots$ & $\ldots$ & $\ldots$ & $\ldots$ & $\ldots$ & $\ldots$ \\
\hline YR.CONF. & 1644 & 99.4 & .147 & -.172 & -.008 & 1 & $\ldots$ & $\ldots$ & $\ldots$ & $\ldots$ & $\ldots$ \\
\hline$Y R . M U S C H$ & 934.8 & 811.2 & -.074 & -.068 & -.097 & .387 & 1 & $\ldots$ & $\ldots$ & $\ldots$ & $\ldots$ \\
\hline YR.CATPRO & 210.8 & 539.8 & .195 & -.212 & -.139 & .095 & -.310 & 1 & $\ldots$ & $\ldots$ & $\ldots$ \\
\hline$M I D E A S T$ & .212 & .412 & -.034 & .131 & -.020 & .063 & .079 & -.176 & -.129 & 1 & $\ldots$ \\
\hline$B A L K A N S$ & .115 & .323 & .093 & .049 & -.105 & .148 & .328 & -.131 & -.096 & -.162 & 1 \\
\hline EASTEU & .096 & .298 & .243 & -.093 & -.008 & -.035 & .216 & -.041 & .070 & -.217 & -.162 \\
\hline
\end{tabular}


Table 2: Continued

\begin{tabular}{|c|c|c|c|c|c|c|c|c|c|c|c|}
\hline \multicolumn{3}{|c|}{$1400 \mathrm{CE}-1900 \mathrm{CE}$} & \multicolumn{9}{|c|}{ The Correlation Matrix } \\
\hline$n=52$ & Mean & St. Dev. & $R E L I G$ & $E T H N$ & $L I N G$ & $E Q U$ & $R O M E$ & $J E R U S$ & $M E C C A$ & $C H R S M$ & $M U S M A J$ \\
\hline$R E L I G F R A C$ & .369 & .222 & 1 & $\ldots$ & $\ldots$ & $\ldots$ & $\ldots$ & $\ldots$ & $\ldots$ & $\ldots$ & $\ldots$ \\
\hline ETHNOFRAC & .304 & .204 & .087 & 1 & $\ldots$ & $\ldots$ & $\ldots$ & $\ldots$ & $\ldots$ & $\ldots$ & $\ldots$ \\
\hline$L I N G O F R A C$ & .269 & .215 & .296 & .688 & 1 & $\ldots$ & $\ldots$ & $\ldots$ & $\ldots$ & $\ldots$ & $\ldots$ \\
\hline$E Q U A T O R$ & 42.7 & 11.0 & .309 & -.219 & .010 & 1 & $\ldots$ & $\ldots$ & $\ldots$ & $\ldots$ & $\ldots$ \\
\hline$R O M E$ & 1093 & 663.7 & -.095 & .231 & .255 & -.337 & 1 & $\ldots$ & $\ldots$ & $\ldots$ & $\ldots$ \\
\hline JERUS. & 1951 & 763.3 & -.035 & -.093 & -.002 & .557 & -.172 & 1 & $\ldots$ & $\ldots$ & $\ldots$ \\
\hline$M E C C A$ & 1368 & 650.0 & .073 & -.121 & -.004 & .709 & -.344 & .904 & 1 & $\ldots$ & $\ldots$ \\
\hline CHRMAJOR & .635 & .486 & -.438 & .153 & -.126 & -.665 & .302 & -.384 & -.499 & 1 & $\ldots$ \\
\hline MUSMAJOR & .269 & .448 & .245 & -.285 & -.111 & .703 & -.401 & .483 & .568 & -.780 & 1 \\
\hline POLITY94 & 5.02 & 6.02 & .231 & -.446 & -.128 & .650 & -.440 & .357 & .475 & -.684 & .747 \\
\hline
\end{tabular}


Table 3: Impact of Conflicts on Religious Fractionalization (1400 - $1900 \mathrm{CE})$

\begin{tabular}{|c|c|c|c|c|}
\hline & \multicolumn{4}{|c|}{ Dependent Variable: Religious Fractionalization } \\
\hline & (1) & (2) & (3) & $(4)$ \\
\hline TOTALCONFLICTS & $\begin{array}{l}.0008 \\
(.002)\end{array}$ & $\begin{array}{l}-.001 \\
(.003)\end{array}$ & $\begin{array}{l}.0002 \\
(.006)\end{array}$ & $\begin{array}{c}.003 \\
(.007)\end{array}$ \\
\hline MUSLIMCHRISTIAN & $\begin{array}{c}-.016^{* *} \\
(.008)\end{array}$ & $\begin{array}{c}-.020^{*} \\
(.007)\end{array}$ & $\begin{array}{c}-.019^{* *} \\
(.010)\end{array}$ & $\begin{array}{c}-.022^{* *} \\
(.011)\end{array}$ \\
\hline PROTESTCATHOLIC & $\begin{array}{c}.002 \\
(.016)\end{array}$ & $\begin{array}{c}-.0005 \\
(.018)\end{array}$ & $\begin{array}{c}.002 \\
(.035)\end{array}$ & $\begin{array}{c}.028 \\
(.051)\end{array}$ \\
\hline POGROM & $\begin{array}{c}.117 \\
(.153)\end{array}$ & $\begin{array}{c}.218 \\
(.161)\end{array}$ & $\begin{array}{c}.329 \\
(.199)\end{array}$ & $\begin{array}{l}.682^{*} \\
(.240)\end{array}$ \\
\hline DURCONFLICTS & $\begin{array}{l}.053^{*} \\
(.025)\end{array}$ & $\begin{array}{l}.054^{*} \\
(.026)\end{array}$ & $\begin{array}{l}.062^{* *} \\
(.032)\end{array}$ & $\begin{array}{c}.053 \\
(.034)\end{array}$ \\
\hline$\overline{D U R M U S L I M C H R I S T}$ & $\begin{array}{l}-.031 \\
(.021)\end{array}$ & $\begin{array}{c}.033^{* *} \\
(.019)\end{array}$ & $\begin{array}{l}-.039 \\
(.025)\end{array}$ & $\begin{array}{l}-.027 \\
(.029)\end{array}$ \\
\hline DURPROTESTCATH & $\begin{array}{c}.006 \\
(.011) \\
\end{array}$ & $\begin{array}{c}.003 \\
(.010) \\
\end{array}$ & $\begin{array}{c}.008 \\
(.011) \\
\end{array}$ & $\begin{array}{c}.012 \\
(.025) \\
\end{array}$ \\
\hline$\overline{D U R P O G R O M}$ & $\begin{array}{l}-.191 \\
(.246)\end{array}$ & $\begin{array}{l}-.347 \\
(.228)\end{array}$ & $\begin{array}{c}-.623^{*} \\
(.285)\end{array}$ & $\begin{array}{l}-.136 \\
(.576)\end{array}$ \\
\hline$B A L K A N S$ & $\begin{array}{l}.532^{*} \\
(.075)\end{array}$ & $\begin{array}{l}.509^{*} \\
(.129)\end{array}$ & $\begin{array}{c}.333 \\
(.213)\end{array}$ & $\begin{array}{l}.416^{* *} \\
(.232)\end{array}$ \\
\hline EASTERNEU & $\begin{array}{l}.513^{*} \\
(.092) \\
\end{array}$ & $\begin{array}{l}.422^{* *} \\
(.239) \\
\end{array}$ & $\begin{array}{c}.204 \\
(.329) \\
\end{array}$ & $\begin{array}{c}.296 \\
(.383) \\
\end{array}$ \\
\hline$M I D E A S T$ & $\begin{array}{l}.250^{*} \\
(.063)\end{array}$ & $\begin{array}{l}.253^{*} \\
(.070)\end{array}$ & $\begin{array}{l}-.014 \\
(.192)\end{array}$ & $\begin{array}{c}.040 \\
(.218)\end{array}$ \\
\hline$A F R I C A$ & $\begin{array}{c}.013 \\
(.067)\end{array}$ & $\begin{array}{l}-.219 \\
(.237)\end{array}$ & $\begin{array}{c}.114 \\
(.343)\end{array}$ & $\begin{array}{c}.585 \\
(1.16)\end{array}$ \\
\hline$L A N D A R E A$ & $\ldots$ & $\begin{array}{c}.00001 \\
(.00001)\end{array}$ & $\begin{array}{c}.00002 \\
(.00003) \\
\end{array}$ & $\begin{array}{c}.00003 \\
(.00003) \\
\end{array}$ \\
\hline MUSLIMAJOR & $\ldots$ & $\ldots$ & $\begin{array}{l}-.130 \\
(.184)\end{array}$ & $\begin{array}{l}-.149 \\
(.251)\end{array}$ \\
\hline CHRISTIANMAJOR & $\ldots$ & $\ldots$ & $\begin{array}{l}-.147 \\
(.135)\end{array}$ & $\begin{array}{l}-.122 \\
(.178)\end{array}$ \\
\hline$R^{2}$ & .439 & .478 & .586 & .616 \\
\hline No. of obs. & 52 & 52 & 52 & 52 \\
\hline
\end{tabular}

Note: ${ }^{*}$ and ${ }^{* *}$ respectively denote significance at the 5 percent and 10 percent levels. Dependent variable: religious fractionalization in 2001; source: Alesina et al. (2003). Source of conflict data: Brecke (1999). Source of population data: McEvedy and Jones (1978). Geographic dummy variables WESTERNEU, CENTRALEU, ISLAND, NORTHERNEU included in all regressions but now shown. POPULATION, EQUATOR, LANDLOCK included in columns (2) through (4) but not shown. POP1000, POP1500, ROME, JERUSALEM, MECCA included in columns (3) and (4) but not shown. YRCONFLICT, YRMUSLIMCHRIST, YRPROTESTCATH and YRPOGROM included in column (4) but not shown. 
Table 4: Impact of Conflicts on Ethnic Fractionalization (1400 - $1900 \mathrm{CE})$

\begin{tabular}{|c|c|c|c|c|}
\hline & \multicolumn{4}{|c|}{ Dependent Variable: Ethnic Fractionalization } \\
\hline & (1) & (2) & (3) & $(4)$ \\
\hline TOTALCONFLICTS & $\begin{array}{c}-.0026^{* *} \\
(.0015)\end{array}$ & $\begin{array}{l}-.0026 \\
(.0021)\end{array}$ & $\begin{array}{c}.0011 \\
(.0056)\end{array}$ & $\begin{array}{c}.0091 \\
(.0099)\end{array}$ \\
\hline MUSLIMCHRISTIAN & $\begin{array}{l}-.0010 \\
(.0072)\end{array}$ & $\begin{array}{l}-.0063 \\
(.0087)\end{array}$ & $\begin{array}{l}-.015 \\
(.012)\end{array}$ & $\begin{array}{l}-.024 \\
(.015)\end{array}$ \\
\hline PROTESTCATHOLIC & $\begin{array}{c}-.0001 \\
(.011)\end{array}$ & $\begin{array}{c}-.0029 \\
(.013)\end{array}$ & $\begin{array}{c}.008 \\
(.027)\end{array}$ & $\begin{array}{c}.079 \\
(.069)\end{array}$ \\
\hline POGROM & $\begin{array}{c}.152 \\
(.134)\end{array}$ & $\begin{array}{c}.197 \\
(.153)\end{array}$ & $\begin{array}{l}.138 \\
(.200)\end{array}$ & $\begin{array}{l}.641^{*} \\
(.263)\end{array}$ \\
\hline DURCONFLICTS & $\begin{array}{c}.029 \\
(.025)\end{array}$ & $\begin{array}{l}.048^{* *} \\
(.028)\end{array}$ & $\begin{array}{c}.038 \\
(.034)\end{array}$ & $\begin{array}{c}.021 \\
(.037)\end{array}$ \\
\hline$\overline{D U R M U S L I M C H R I S T}$ & $\begin{array}{c}-.037^{*} \\
(.017)\end{array}$ & $\begin{array}{c}-.051^{*} \\
(.019)\end{array}$ & $\begin{array}{l}-.041 \\
(.026)\end{array}$ & $\begin{array}{l}-.023 \\
(.030)\end{array}$ \\
\hline DURPROTESTCATH & $\begin{array}{l}-.010 \\
(.013)\end{array}$ & $\begin{array}{l}-.012 \\
(.013)\end{array}$ & $\begin{array}{l}-.007 \\
(.015)\end{array}$ & $\begin{array}{c}.014 \\
(.028)\end{array}$ \\
\hline DURPOGROM & $\begin{array}{l}-.314 \\
(.209) \\
\end{array}$ & $\begin{array}{c}-.435^{* *} \\
(.238)\end{array}$ & $\begin{array}{l}-.511 \\
(.370)\end{array}$ & $\begin{array}{l}.250 \\
(.741)\end{array}$ \\
\hline$B A L K A N S$ & $\begin{array}{l}-.002 \\
(.231)\end{array}$ & $\begin{array}{c}.127 \\
(.275)\end{array}$ & $\begin{array}{l}.181 \\
(.367)\end{array}$ & $\begin{array}{c}.290 \\
(.402)\end{array}$ \\
\hline EASTERNEU & $\begin{array}{l}-.039 \\
(.239)\end{array}$ & $\begin{array}{l}-.076 \\
(.290)\end{array}$ & $\begin{array}{c}.080 \\
(.429)\end{array}$ & $\begin{array}{c}.111 \\
(.495)\end{array}$ \\
\hline$M I D E A S T$ & $\begin{array}{l}-.039 \\
(.242)\end{array}$ & $\begin{array}{l}-.026 \\
(.234)\end{array}$ & $\begin{array}{l}-.405 \\
(.391)\end{array}$ & $\begin{array}{l}-.307 \\
(.449)\end{array}$ \\
\hline$A F R I C A$ & $\begin{array}{c}.443 \\
(.276)\end{array}$ & $\begin{array}{c}.468 \\
(.344)\end{array}$ & $\begin{array}{c}.466 \\
(.476)\end{array}$ & $\begin{array}{c}.962 \\
(1.20)\end{array}$ \\
\hline$\overline{L A N D A R E A}$ & $\ldots$ & $\begin{array}{l}.00003^{* *} \\
(.000015)\end{array}$ & $\begin{array}{c}.00002 \\
(.00002)\end{array}$ & $\begin{array}{c}.00004 \\
(.00003)\end{array}$ \\
\hline MUSLIMAJOR & $\ldots$ & $\ldots$ & $\begin{array}{l}-.093 \\
(.161)\end{array}$ & $\begin{array}{l}-.119 \\
(.221)\end{array}$ \\
\hline CHRISTIANMAJOR & $\ldots$ & $\ldots$ & $\begin{array}{l}-.113 \\
(.149)\end{array}$ & $\begin{array}{l}-.090 \\
(.189)\end{array}$ \\
\hline$R^{2}$ & .265 & .328 & .428 & .510 \\
\hline No. of obs. & 50 & 50 & 50 & 50 \\
\hline
\end{tabular}

Note: ${ }^{*}$ and ${ }^{* *}$ respectively denote significance at the 5 percent and 10 percent levels. Dependent variable: religious fractionalization in 2001; source: Alesina et al. (2003). Source of conflict data: Brecke (1999). Source of population data: McEvedy and Jones (1978). Geographic dummy variables WESTERNEU, CENTRALEU, ISLAND, NORTHERNEU included in all regressions but now shown. POPULATION, EQUATOR, LANDLOCK included in columns (2) through (4) but not shown. POP1000, POP1500, ROME, JERUSALEM, MECCA included in columns (3) and (4) but not shown. YRCONFLICT, YRMUSLIMCHRIST, YRPROTESTCATH and YRPOGROM included in column (4) but not shown. 
Table 5: Impact of Conflicts on Linguistic Fractionalization (1400 - 1900 CE)

\begin{tabular}{|c|c|c|c|c|}
\hline & \multicolumn{4}{|c|}{ Dependent Variable: Linguistic Fractionalization } \\
\hline & (1) & (2) & $(3)$ & (4) \\
\hline TOTALCONFLICTS & $\begin{array}{c}-.0031^{* *} \\
(.0017)\end{array}$ & $\begin{array}{c}-.0037^{* *} \\
(.0022)\end{array}$ & $\begin{array}{l}-.0012 \\
(.0050)\end{array}$ & $\begin{array}{c}.0075 \\
(.0089)\end{array}$ \\
\hline MUSLIMCHRISTIAN & $\begin{array}{c}.0043 \\
(.0089)\end{array}$ & $\begin{array}{l}.0003 \\
(.010)\end{array}$ & $\begin{array}{c}-.0077 \\
(.010)\end{array}$ & $\begin{array}{l}-.021 \\
(.013)\end{array}$ \\
\hline PROTESTCATHOLIC & $\begin{array}{c}-.0064 \\
(.015)\end{array}$ & $\begin{array}{l}-.014 \\
(.019)\end{array}$ & $\begin{array}{l}.0087 \\
(.030)\end{array}$ & $\begin{array}{c}.077 \\
(.060)\end{array}$ \\
\hline POGROM & $\begin{array}{c}.041 \\
(.097)\end{array}$ & $\begin{array}{l}.143 \\
(.137)\end{array}$ & $\begin{array}{c}.138 \\
(.175)\end{array}$ & $\begin{array}{c}.414 \\
(.243)\end{array}$ \\
\hline DURCONFLICTS & $\begin{array}{c}.043 \\
(.027)\end{array}$ & $\begin{array}{l}.060^{*} \\
(.030)\end{array}$ & $\begin{array}{c}.052 \\
(.038)\end{array}$ & $\begin{array}{c}.019 \\
(.033)\end{array}$ \\
\hline$\overline{D U R M U S L I M C H R I S T}$ & $\begin{array}{l}-.024 \\
(.020)\end{array}$ & $\begin{array}{l}-.037 \\
(.024)\end{array}$ & $\begin{array}{l}-.039 \\
(.034)\end{array}$ & $\begin{array}{l}-.023 \\
(.032)\end{array}$ \\
\hline DURPROTESTCATH & $\begin{array}{c}-.0046 \\
(.015)\end{array}$ & $\begin{array}{l}-.008 \\
(.018) \\
\end{array}$ & $\begin{array}{c}-.0035 \\
(.019) \\
\end{array}$ & $\begin{array}{c}.016 \\
(.028) \\
\end{array}$ \\
\hline$\overline{D U R P O G R O M}$ & $\begin{array}{c}.030 \\
(.211)\end{array}$ & $\begin{array}{l}-.186 \\
(.163)\end{array}$ & $\begin{array}{l}-.558 \\
(.407)\end{array}$ & $\begin{array}{c}.197 \\
(.584)\end{array}$ \\
\hline$B A L K A N S$ & $\begin{array}{l}.050 \\
(.183)\end{array}$ & $\begin{array}{c}.073 \\
(.226)\end{array}$ & $\begin{array}{c}.039 \\
(.267)\end{array}$ & $\begin{array}{c}.063 \\
(.290)\end{array}$ \\
\hline EASTERNEU & $\begin{array}{c}.155 \\
(.151) \\
\end{array}$ & $\begin{array}{l}-.043 \\
(.234) \\
\end{array}$ & $\begin{array}{c}.090 \\
(.313) \\
\end{array}$ & $\begin{array}{l}-.064 \\
(.362) \\
\end{array}$ \\
\hline$M I D E A S T$ & $\begin{array}{c}.112 \\
(.133)\end{array}$ & $\begin{array}{c}.113 \\
(.124)\end{array}$ & $\begin{array}{l}-.525^{*} \\
(.232)\end{array}$ & $\begin{array}{l}-.414 \\
(.334)\end{array}$ \\
\hline$A F R I C A$ & $\begin{array}{c}.125 \\
(.135)\end{array}$ & $\begin{array}{l}-.072 \\
(.258)\end{array}$ & $\begin{array}{c}.247 \\
(.352) \\
\end{array}$ & $\begin{array}{c}.604 \\
(1.05)\end{array}$ \\
\hline$L A N D A R E A$ & $\ldots$ & $\begin{array}{c}.00002 \\
(.00002) \\
\end{array}$ & $\begin{array}{c}.00002 \\
(.00002) \\
\end{array}$ & $\begin{array}{c}.00003 \\
(.00003) \\
\end{array}$ \\
\hline$M U S L I M A J O R$ & $\ldots$ & $\ldots$ & $\begin{array}{c}-.297^{* *} \\
(.179)\end{array}$ & $\begin{array}{c}-.364^{*} \\
(.145)\end{array}$ \\
\hline CHRISTIANMAJOR & $\ldots$ & $\ldots$ & $\begin{array}{l}-.296 \\
(.179)\end{array}$ & $\begin{array}{c}-.343^{*} \\
(.157)\end{array}$ \\
\hline$R^{2}$ & .245 & .311 & .562 & .675 \\
\hline No. of obs. & 52 & 52 & 52 & 52 \\
\hline
\end{tabular}

Note: ${ }^{*}$ and ${ }^{* *}$ respectively denote significance at the 5 percent and 10 percent levels. Dependent variable: religious fractionalization in 2001; source: Alesina et al. (2003). Source of conflict data: Brecke (1999). Source of population data: McEvedy and Jones (1978). Geographic dummy variables WESTERNEU, CENTRALEU, ISLAND, NORTHERNEU included in all regressions but now shown. POPULATION, EQUATOR, LANDLOCK included in columns (2) through (4) but not shown. POP1000, POP1500, ROME, JERUSALEM, MECCA included in columns (3) and (4) but not shown. YRCONFLICT, YRMUSLIMCHRIST, YRPROTESTCATH and YRPOGROM included in column (4) but not shown. 
Table 6: Impact of Conflicts on Religious Fractionalization (1400 - $1600 \mathrm{CE})$

\begin{tabular}{|c|c|c|c|c|}
\hline & \multicolumn{4}{|c|}{ Dependent Variable: Religious Fractionalization } \\
\hline & (1) & (2) & (3) & (4) \\
\hline TOTALCONFLICTS & $\begin{array}{c}-.0003 \\
(.003)\end{array}$ & $\begin{array}{l}-.002 \\
(.003)\end{array}$ & $\begin{array}{l}.0003 \\
(.007)\end{array}$ & $\begin{array}{c}.007 \\
(.006)\end{array}$ \\
\hline MUSLIMCHRISTIAN & $\begin{array}{l}-.022 \\
(.016)\end{array}$ & $\begin{array}{l}-.026 \\
(.017)\end{array}$ & $\begin{array}{l}-.025 \\
(.024)\end{array}$ & $\begin{array}{c}-.033^{* *} \\
(.018)\end{array}$ \\
\hline PROTESTCATHOLIC & $\begin{array}{l}.047^{*} \\
(.021)\end{array}$ & $\begin{array}{l}.049^{* *} \\
(.023)\end{array}$ & $\begin{array}{l}.063^{*} \\
(.035)\end{array}$ & $\begin{array}{l}.355^{*} \\
(.072)\end{array}$ \\
\hline POGROM & $\begin{array}{l}.531^{*} \\
(.154)\end{array}$ & $\begin{array}{l}.589^{* * *} \\
(.155)\end{array}$ & $\begin{array}{l}.683^{* *} \\
(.168)\end{array}$ & $\begin{array}{l}1.64^{*} \\
(.300)\end{array}$ \\
\hline DURCONFLICTS & $\begin{array}{l}.016 \\
(.011)\end{array}$ & $\begin{array}{c}.012 \\
(.012)\end{array}$ & $\begin{array}{c}.013 \\
(.012)\end{array}$ & $\begin{array}{l}-.028 \\
(.021)\end{array}$ \\
\hline$\overline{D U R M U S L I M C H R I S T}$ & $\begin{array}{l}-.010 \\
(.017)\end{array}$ & $\begin{array}{l}-.002 \\
(.015)\end{array}$ & $\begin{array}{l}.006 \\
(.021)\end{array}$ & $\begin{array}{c}.043 \\
(.027)\end{array}$ \\
\hline DURPROTESTCATH & $\begin{array}{l}-.005 \\
(.018)\end{array}$ & $\begin{array}{c}-.0001 \\
(.017)\end{array}$ & $\begin{array}{l}.009 \\
(.021)\end{array}$ & $\begin{array}{c}.001 \\
(.025)\end{array}$ \\
\hline$\overline{D U R P O G R O M}$ & $\begin{array}{l}-9.48^{*} \\
(3.62)\end{array}$ & $\begin{array}{l}-9.68^{*} \\
(3.63)\end{array}$ & $\begin{array}{l}-9.57^{*} \\
(3.767)\end{array}$ & $\begin{array}{c}-385.3^{*} \\
(72.16)\end{array}$ \\
\hline$B A L K A N S$ & $\begin{array}{l}.444^{*} \\
(.070)\end{array}$ & $\begin{array}{l}.415^{*} \\
(.136)\end{array}$ & $\begin{array}{l}.275 \\
(.230)\end{array}$ & $\begin{array}{c}.019 \\
(.330)\end{array}$ \\
\hline EASTERNEU & $\begin{array}{l}.462^{*} \\
(.069) \\
\end{array}$ & $\begin{array}{l}.423^{* *} \\
(.172) \\
\end{array}$ & $\begin{array}{c}.328 \\
(.336) \\
\end{array}$ & $\begin{array}{c}.077 \\
(.382) \\
\end{array}$ \\
\hline$M I D E A S T$ & $\begin{array}{l}.212^{*} \\
(.088)\end{array}$ & $\begin{array}{l}.224^{*} \\
(.099)\end{array}$ & $\begin{array}{c}.124 \\
(.217)\end{array}$ & $\begin{array}{l}-.174 \\
(.244)\end{array}$ \\
\hline$A F R I C A$ & $\begin{array}{l}-.080 \\
(.071)\end{array}$ & $\begin{array}{l}-.061 \\
(.254)\end{array}$ & $\begin{array}{l}.236 \\
(.274)\end{array}$ & $\begin{array}{l}.360^{*} \\
(.454)\end{array}$ \\
\hline$L A N D A R E A$ & $\ldots$ & $\begin{array}{c}.00000001 \\
(.00000001) \\
\end{array}$ & $\begin{array}{c}.00000002 \\
(.00000002) \\
\end{array}$ & $\begin{array}{c}.00000002 \\
(.00000002) \\
\end{array}$ \\
\hline MUSLIMAJOR & $\ldots$ & $\ldots$ & $\begin{array}{l}-.179 \\
(.178)\end{array}$ & $\begin{array}{c}-.363^{* *} \\
(.187)\end{array}$ \\
\hline CHRISTIANMAJOR & $\ldots$ & $\ldots$ & $\begin{array}{l}-.142 \\
(.117)\end{array}$ & $\begin{array}{l}-.278^{*} \\
(.132)\end{array}$ \\
\hline$R^{2}$ & .455 & .474 & .600 & .754 \\
\hline No. of obs. & 52 & 52 & 52 & 52 \\
\hline
\end{tabular}

Note: ${ }^{*}$ and ${ }^{* *}$ respectively denote significance at the 5 percent and 10 percent levels. Dependent variable: religious fractionalization in 2001; source: Alesina et al. (2003). Source of conflict data: Brecke (1999). Source of population data: McEvedy and Jones (1978). Geographic dummy variables WESTERNEU, CENTRALEU, ISLAND, NORTHERNEU included in all regressions but not shown. POPULATION, EQUATOR, LANDLOCK included in columns (2) through (4) but not shown. POP1000, POP1500, ROME, JERUSALEM, MECCA included in columns (3) and (4) but not shown. YRCONFLICT, YRMUSLIMCHRIST, YRPROTESTCATH and YRPOGROM included in column (4) but not shown. 
Table 7: Impact of Conflicts on Ethnic Fractionalization (1400 - 1600 CE)

\begin{tabular}{|c|c|c|c|c|}
\hline & \multicolumn{4}{|c|}{ Dependent Variable: Ethnic Fractionalization } \\
\hline & (1) & (2) & (3) & (4) \\
\hline TOTALCONFLICTS & $\begin{array}{c}.005^{* *} \\
(.002)\end{array}$ & $\begin{array}{l}-.004 \\
(.003)\end{array}$ & $\begin{array}{c}.003 \\
(.007)\end{array}$ & $\begin{array}{c}.012 \\
(.011)\end{array}$ \\
\hline MUSLIMCHRISTIAN & $\begin{array}{c}.003 \\
(.021)\end{array}$ & $\begin{array}{l}-.007 \\
(.020)\end{array}$ & $\begin{array}{l}-.019 \\
(.026)\end{array}$ & $\begin{array}{l}-.036 \\
(.025)\end{array}$ \\
\hline PROTESTCATHOLIC & $\begin{array}{c}.022 \\
(.017)\end{array}$ & $\begin{array}{l}.020 \\
(.019)\end{array}$ & $\begin{array}{c}.031 \\
(.052)\end{array}$ & $\begin{array}{l}.111 \\
(.107)\end{array}$ \\
\hline POGROM & $\begin{array}{l}.411^{*} \\
(.087)\end{array}$ & $\begin{array}{l}.467^{*} \\
(.139)\end{array}$ & $\begin{array}{l}.400^{*} \\
(.189)\end{array}$ & $\begin{array}{c}.667 \\
(.432)\end{array}$ \\
\hline DURCONFLICTS & $\begin{array}{l}.016 \\
(.015)\end{array}$ & $\begin{array}{l}.026^{* *} \\
(.014)\end{array}$ & $\begin{array}{l}.020 \\
(.017)\end{array}$ & $\begin{array}{l}-.016 \\
(.035)\end{array}$ \\
\hline$\overline{D U R M U S L I M C H R I S T}$ & $\begin{array}{l}-.003 \\
(.018)\end{array}$ & $\begin{array}{l}-.014 \\
(.021)\end{array}$ & $\begin{array}{l}-.002 \\
(.026)\end{array}$ & $\begin{array}{c}.032 \\
(.044)\end{array}$ \\
\hline DURPROTESTCATH & $\begin{array}{l}-.003 \\
(.014) \\
\end{array}$ & $\begin{array}{l}-.006 \\
(.014)\end{array}$ & $\begin{array}{c}.001 \\
(.018) \\
\end{array}$ & $\begin{array}{l}.077^{*} \\
(.036) \\
\end{array}$ \\
\hline$\overline{D U R P O G R O M}$ & $\begin{array}{c}-6.62^{*} \\
(2.49)\end{array}$ & $\begin{array}{l}-7.67^{*} \\
(3.366)\end{array}$ & $\begin{array}{l}-7.07^{* *} \\
(3.832)\end{array}$ & $\begin{array}{c}-8.27 \\
(118.5)\end{array}$ \\
\hline$B A L K A N S$ & $\begin{array}{l}-.047 \\
(.220)\end{array}$ & $\begin{array}{c}.074 \\
(.247)\end{array}$ & $\begin{array}{l}.155 \\
(.310)\end{array}$ & $\begin{array}{c}-.031 \\
(.452)\end{array}$ \\
\hline EASTERNEU & $\begin{array}{l}-.079 \\
(.219)\end{array}$ & $\begin{array}{l}-.114 \\
(.266)\end{array}$ & $\begin{array}{c}.093 \\
(.358)\end{array}$ & $\begin{array}{l}-.084 \\
(.484)\end{array}$ \\
\hline$M I D E A S T$ & $\begin{array}{c}.003 \\
(.242)\end{array}$ & $\begin{array}{l}-.002 \\
(.231)\end{array}$ & $\begin{array}{l}-.237 \\
(.329)\end{array}$ & $\begin{array}{l}-.202 \\
(.403)\end{array}$ \\
\hline$A F R I C A$ & $\begin{array}{c}.360 \\
(.241)\end{array}$ & $\begin{array}{c}.481 \\
(.353)\end{array}$ & $\begin{array}{c}.464 \\
(.400)\end{array}$ & $\begin{array}{l}-.090 \\
(.541)\end{array}$ \\
\hline$L A N D A R E A$ & $\ldots$ & $\begin{array}{l}.00000003 \\
(.0000002) \\
\end{array}$ & $\begin{array}{c}.00000002 \\
(.00000002) \\
\end{array}$ & $\begin{array}{l}.00000003 \\
(.0000002) \\
\end{array}$ \\
\hline MUSLIMAJOR & $\ldots$ & $\ldots$ & $\begin{array}{l}-.094 \\
(.178)\end{array}$ & $\begin{array}{l}-.257 \\
(.174) \\
\end{array}$ \\
\hline CHRISTIANMAJOR & $\ldots$ & $\ldots$ & $\begin{array}{l}-.077 \\
(.123)\end{array}$ & $\begin{array}{l}-.153 \\
(.137)\end{array}$ \\
\hline$R^{2}$ & .267 & .329 & .444 & .580 \\
\hline No. of obs. & 50 & 50 & 50 & 50 \\
\hline
\end{tabular}

Note: ${ }^{*}$ and ${ }^{* *}$ respectively denote significance at the 5 percent and 10 percent levels. Dependent variable: religious fractionalization in 2001; source: Alesina et al. (2003). Source of conflict data: Brecke (1999). Source of population data: McEvedy and Jones (1978). Geographic dummy variables WESTERNEU, CENTRALEU, ISLAND, NORTHERNEU included in all regressions but not shown. POPULATION, EQUATOR, LANDLOCK included in columns (2) through (4) but not shown. POP1000, POP1500, ROME, JERUSALEM, MECCA included in columns (3) and (4) but not shown. YRCONFLICT, YRMUSLIMCHRIST, YRPROTESTCATH and YRPOGROM included in column (4) but not shown. 
Table 8: Impact of Conflicts on Linguistic Fractionalization (1400 - 1600 CE)

\begin{tabular}{|c|c|c|c|c|}
\hline & \multicolumn{4}{|c|}{ Dependent Variable: Linguistic Fractionalization } \\
\hline & (1) & (2) & (3) & (4) \\
\hline TOTALCONFLICTS & $\begin{array}{c}-.006^{*} \\
(.002)\end{array}$ & $\begin{array}{c}-.007^{* * *} \\
(.004)\end{array}$ & $\begin{array}{c}-.0006 \\
(.006)\end{array}$ & $\begin{array}{l}.0007 \\
(.008)\end{array}$ \\
\hline MUSLIMCHRISTIAN & $\begin{array}{l}.003 \\
(.019)\end{array}$ & $\begin{array}{l}-.004 \\
(.024)\end{array}$ & $\begin{array}{l}-.007 \\
(.022)\end{array}$ & $\begin{array}{c}-.037^{* *} \\
(.022)\end{array}$ \\
\hline PROTESTCATHOLIC & $\begin{array}{c}.025 \\
(.020)\end{array}$ & $\begin{array}{c}.019 \\
(.025)\end{array}$ & $\begin{array}{c}.055 \\
(.044)\end{array}$ & $\begin{array}{c}.049 \\
(.097)\end{array}$ \\
\hline POGROM & $\begin{array}{l}.396^{* *} \\
(.115)\end{array}$ & $\begin{array}{l}.453^{* *} \\
(.192)\end{array}$ & $\begin{array}{l}.390^{*} \\
(.192)\end{array}$ & $\begin{array}{l}.356^{*} \\
(.372)\end{array}$ \\
\hline DURCONFLICTS & $\begin{array}{l}.015 \\
(.013)\end{array}$ & $\begin{array}{l}.024 \\
(.015)\end{array}$ & $\begin{array}{c}.017 \\
(.019)\end{array}$ & $\begin{array}{l}-.002 \\
(.030)\end{array}$ \\
\hline$\overline{D U R M U S L I M C H R I S T}$ & $\begin{array}{c}-.0008 \\
(.021)\end{array}$ & $\begin{array}{l}-.010 \\
(.026)\end{array}$ & $\begin{array}{l}-.003 \\
(.032)\end{array}$ & $\begin{array}{c}.014 \\
(.036)\end{array}$ \\
\hline DURPROTESTCATH & $\begin{array}{l}.00006 \\
(.016)\end{array}$ & $\begin{array}{c}-.0002 \\
(.016)\end{array}$ & $\begin{array}{l}.015 \\
(.017)\end{array}$ & $\begin{array}{l}.084 \\
(.036)\end{array}$ \\
\hline$\overline{D U R P O G R O M}$ & $\begin{array}{l}-8.43^{*} \\
(2.00)\end{array}$ & $\begin{array}{l}-8.67^{*} \\
(3.210)\end{array}$ & $\begin{array}{l}-7.54^{*} \\
(2.848)\end{array}$ & $\begin{array}{c}-94.81 \\
(117.67)\end{array}$ \\
\hline$B A L K A N S$ & $\begin{array}{l}.025 \\
(.177)\end{array}$ & $\begin{array}{l}.046 \\
(.231)\end{array}$ & $\begin{array}{l}.155 \\
(.266)\end{array}$ & $\begin{array}{c}-.015 \\
(.292)\end{array}$ \\
\hline EASTERNEU & $\begin{array}{c}.143 \\
(.132) \\
\end{array}$ & $\begin{array}{l}-.040 \\
(.245) \\
\end{array}$ & $\begin{array}{c}.150 \\
(.227) \\
\end{array}$ & $\begin{array}{c}.150 \\
(.281) \\
\end{array}$ \\
\hline$M I D E A S T$ & $\begin{array}{l}.124^{* *} \\
(.145)\end{array}$ & $\begin{array}{c}.116 \\
(.169)\end{array}$ & $\begin{array}{l}-.393 \\
(.222)\end{array}$ & $\begin{array}{l}-.316 \\
(.294)\end{array}$ \\
\hline$A F R I C A$ & $\begin{array}{c}.128 \\
(.151)\end{array}$ & $\begin{array}{l}-.191 \\
(.171)\end{array}$ & $\begin{array}{c}.316 \\
(.289)\end{array}$ & $\begin{array}{l}-.121 \\
(.413)\end{array}$ \\
\hline$L A N D A R E A$ & $\ldots$ & $\begin{array}{l}.0000002 \\
(.000002) \\
\end{array}$ & $\begin{array}{c}.00000003 \\
(.00000002) \\
\end{array}$ & $\begin{array}{c}.00000003 \\
(.00000002) \\
\end{array}$ \\
\hline MUSLIMAJOR & $\ldots$ & $\ldots$ & $\begin{array}{c}-.326^{*} \\
(.172)\end{array}$ & $\begin{array}{c}-.400^{*} \\
(.181)\end{array}$ \\
\hline CHRISTIANMAJOR & $\ldots$ & $\ldots$ & $\begin{array}{c}-.251^{* *} \\
(.145)\end{array}$ & $\begin{array}{c}-.299^{* *} \\
(.151)\end{array}$ \\
\hline$R^{2}$ & .223 & .315 & .592 & .690 \\
\hline No. of obs. & 52 & 52 & 52 & 52 \\
\hline
\end{tabular}

Note: ${ }^{*}$ and ${ }^{* *}$ respectively denote significance at the 5 percent and 10 percent levels. Dependent variable: religious fractionalization in 2001; source: Alesina et al. (2003). Source of conflict data: Brecke (1999). Source of population data: McEvedy and Jones (1978). Geographic dummy variables WESTERNEU, CENTRALEU, ISLAND, NORTHERNEU included in all regressions but not shown. POPULATION, EQUATOR, LANDLOCK included in columns (2) through (4) but not shown. POP1000, POP1500, ROME, JERUSALEM, MECCA included in columns (3) and (4) but not shown. YRCONFLICT, YRMUSLIMCHRIST, YRPROTESTCATH and YRPOGROM included in column (4) but not shown. 
Table 9.A: Three-Stage OLS IV Estimates (1400 - 1900 CE Conflict Data)

\begin{tabular}{|c|c|c|c|}
\hline & \multicolumn{3}{|c|}{ Dep. Var.: Economic Growth (1970-2002) } \\
\hline & (1) & $(2)$ & $(3)$ \\
\hline RELICFRAC & $\begin{array}{l}-3.75^{*} \\
(2.26)\end{array}$ & $\begin{array}{l}-2.80 \\
(1.79)\end{array}$ & $\begin{array}{c}-3.24^{* *} \\
(1.79)\end{array}$ \\
\hline ETHNOFRAC & $\ldots$ & $\begin{array}{c}-4.17^{*} \\
(.990)\end{array}$ & $\begin{array}{c}-3.23^{*} \\
(1.38)\end{array}$ \\
\hline$\overline{L I N G O F R A C}$ & $\cdots$ & $\ldots$ & $\begin{array}{l}-.753 \\
(.961)\end{array}$ \\
\hline$G D P / C A P I T A(1970)$ & $\begin{array}{c}-.00047^{* *} \\
(.00027)\end{array}$ & $\begin{array}{c}-.00043^{*} \\
(.00022)\end{array}$ & $\begin{array}{c}-.0004 \\
(.00022)\end{array}$ \\
\hline POPGROW $(1970)$ & $\begin{array}{c}-.624^{* *} \\
(.336)\end{array}$ & $\begin{array}{c}-.550^{*} \\
(.264)\end{array}$ & $\begin{array}{c}-.534^{*} \\
(.261)\end{array}$ \\
\hline$I N V / G D P(1970)$ & $\begin{array}{c}.046 \\
(.036)\end{array}$ & $\begin{array}{l}.047^{* *} \\
(.028)\end{array}$ & $\begin{array}{l}.049^{* *} \\
(.029)\end{array}$ \\
\hline$O P E N N E S S(1970)$ & $\begin{array}{l}.00045 \\
(.0128)\end{array}$ & $\begin{array}{l}-.0073 \\
(.0104)\end{array}$ & $\begin{array}{c}-.0068 \\
(.010)\end{array}$ \\
\hline PRIMARYSCHOOL $(1970)$ & $\begin{array}{c}-.0034 \\
(.023)\end{array}$ & $\begin{array}{c}-.036^{* *} \\
(.020)\end{array}$ & $\begin{array}{c}-.040^{*} \\
(.020)\end{array}$ \\
\hline$B A L K A N S$ & $\begin{array}{c}.464 \\
(.933)\end{array}$ & $\begin{array}{l}-.116 \\
(.773)\end{array}$ & $\begin{array}{l}-.189 \\
(.768)\end{array}$ \\
\hline$\overline{E A S T E R N E U}$ & $\begin{array}{c}1.18 \\
(1.12)\end{array}$ & $\begin{array}{c}.107 \\
(.942)\end{array}$ & $\begin{array}{c}.217 \\
(.920)\end{array}$ \\
\hline$M I D E A S T$ & $\begin{array}{c}.876 \\
(.711)\end{array}$ & $\begin{array}{l}1.32^{*} \\
(.590)\end{array}$ & $\begin{array}{l}1.27^{*} \\
(.582)\end{array}$ \\
\hline$A F R I C A$ & $\begin{array}{c}2.27 \\
(2.49)\end{array}$ & $\begin{array}{c}6.38^{*} \\
(2.24)\end{array}$ & $\begin{array}{c}6.38^{*} \\
(2.20)\end{array}$ \\
\hline$L A N D A R E A$ & $\begin{array}{l}-.0066 \\
(.0066)\end{array}$ & $\begin{array}{l}-.0020 \\
(.0055)\end{array}$ & $\begin{array}{l}-.0021 \\
(.0054)\end{array}$ \\
\hline$L A N D L O C K E D$ & $\begin{array}{l}-.351 \\
(.691)\end{array}$ & $\begin{array}{l}-.050 \\
(.563)\end{array}$ & $\begin{array}{l}-.109 \\
(.560)\end{array}$ \\
\hline$I S L A N D$ & $\begin{array}{c}\text { (1.00* } \\
(1.33)\end{array}$ & $\begin{array}{c}3.32^{*} \\
(1.11)\end{array}$ & $\begin{array}{c}3.24^{*} \\
(1.09)\end{array}$ \\
\hline$R^{2}$ & .833 & .864 & .879 \\
\hline No. of obs. & 30 & 30 & 30 \\
\hline
\end{tabular}

Note: ${ }^{*}$ and ${ }^{* *}$ respectively denote significance at the 5 percent and 10 percent levels. Dependent variable: religious fractionalization in 2001; source: Alesina et al. (2003). Source of conflict data: Brecke (1999). Source of population data: McEvedy and Jones (1978). Geographic dummy variables WESTERNEU, CENTRALEU, NORTHERNEU included in all regressions but not shown. 
Table 9.B: Three-Stage OLS IV Estimates (1400 - 1900 CE Conflict Data)

Dependent Variables: Religious Fractionalization in (1), (2.a) and (3.a) Ethnic Fractionalization in (2.b) and (3.b)

Linguistic Fractionalization in (3.c)

\begin{tabular}{||l|c|c|c|c|c|c||}
\hline \hline \multicolumn{1}{|c|}{ 2nd Stage } & RELI. & RELI. & ETHN. & RELI. & ETHN. & LINGF. \\
\hline \hline & $(1)$ & $(2 . \mathrm{a})$ & $(2 . \mathrm{b})$ & $(3 . \mathrm{a})$ & $(3 . \mathrm{b})$ & $(3 . \mathrm{c})$ \\
\hline MUSLIMCHRIST. & $-.019^{* *}$ & $-.021^{*}$ & .0018 & $-.020^{*}$ & .0013 & -.0009 \\
& $(.010)$ & $(.010)$ & $(.011)$ & $(.010)$ & $(.011)$ & $(.014)$ \\
\hline PROTESTCATH. & $.033^{*}$ & $.030^{*}$ & $-.025^{* *}$ & $.030^{*}$ & $-.026^{* *}$ & -.020 \\
& $(.014)$ & $(.013)$ & $(.014)$ & $(.014)$ & $(.014)$ & $(.018)$ \\
\hline MIDEAST & $.282^{*}$ & $.282^{*}$ & .091 & $.283^{*}$ & .091 & -.039 \\
& $(.096)$ & $(.096)$ & $(.099)$ & $(.096)$ & $(.099)$ & $(.124)$ \\
\hline BALKANS & $.436^{* *}$ & $.460^{*}$ & -.244 & $.454^{* *}$ & -.235 & -.369 \\
& $(.251)$ & $(.249)$ & $(.262)$ & $(.249)$ & $.262)$ & $(.326)$ \\
\hline EASTERNEU & .257 & .250 & $-.495^{*}$ & .251 & $-.493^{*}$ & $-.496^{* *}$ \\
& $(.221)$ & $(.220)$ & $(.231)$ & $(.220)$ & $(.231)$ & $(.288)$ \\
\hline EQUATOR & .012 & .013 & $.016^{* *}$ & .012 & $.017^{* *}$ & $.020^{* *}$ \\
& $. .009)$ & $(.086)$ & $(.009)$ & $(.009)$ & $(.009)$ & $(.011)$ \\
\hline ISLAND & -.269 & -.271 & -.315 & -.265 & -.318 & $-.508^{* *}$ \\
& $(.235)$ & $(.235)$ & $(.244)$ & $(.235)$ & $.244)$ & $(.303)$ \\
\hline LANDAREA & .002 & .002 & -.00004 & .0017 & .00003 & .0004 \\
& $(.002)$ & $(.002)$ & $(.0015)$ & $(.0014)$ & $(.002)$ & $(.002)$ \\
\hline LANDLOCKED & .160 & .162 & $.217^{* *}$ & .163 & $.216^{* *}$ & .069 \\
& $(.108)$ & $(.108)$ & $(.115)$ & $(.108)$ & $(.115)$ & $(.143)$ \\
\hline$R^{2}$ & .515 & .526 & .436 & .525 & .436 & .272 \\
\hline F statistic & 3.52 & 3.55 & 1.71 & 3.53 & 1.71 & .744 \\
\hline No. of obs. & 30 & 30 & 30 & 30 & 30 & 30 \\
\hline \hline
\end{tabular}

Note: ${ }^{*}$ and ${ }^{* *}$ respectively denote significance at the 5 percent and 10 percent levels. Dependent variables: religious, ethnic and linguistic fractionalization in 2001; source: Alesina et al. (2003). Source of conflict data: Brecke (1999). WESTERNEU, CENTRALEU, NORTHERNEU, AFRICA and POPULATION included but not shown. 
Table 9.C: Three-Stage OLS IV Estimates (1400 - 1900 CE Conflict Data)

\begin{tabular}{||l|c|c|c||}
\hline \hline \multicolumn{1}{|c|}{ 1st Stage } & \multicolumn{3}{|c||}{ Dep. Var.: MUSLIMCHRISTIAN } \\
\hline \hline & $(1)$ & $(2)$ & $(3)$ \\
\hline ROME & $-.087^{*}$ & $-.087^{*}$ & $-.088^{*}$ \\
& $(.013)$ & $(.013)$ & $(.013)$ \\
\hline JERUSALEM & $.023^{*}$ & $.022^{*}$ & $.022^{*}$ \\
& $(.0055)$ & $(.0055)$ & $(.0055)$ \\
\hline MECCA & $-.113^{*}$ & $-.113^{*}$ & $-.115^{*}$ \\
& $(.020)$ & $(.019)$ & $(.019)$ \\
\hline$R O M E-J E R$ & $90.8^{*}$ & $90.3^{*}$ & $91.3^{*}$ \\
& $(16.7)$ & $(16.6)$ & $(16.6)$ \\
\hline JER-MECC & $.000026^{*}$ & $.000027^{*}$ & $.000027^{*}$ \\
& $(.000005)$ & $(.000005)$ & $(.000005)$ \\
\hline$R O M E-M E C C$ & $.000085^{*}$ & $.000086^{*}$ & $.000087^{*}$ \\
& $(.000013)$ & $(.000013)$ & $(.000013)$ \\
\hline$R M-J E-M E$ & $-.0026^{*}$ & $-.0026^{*}$ & $-.0026^{*}$ \\
& $(.00043)$ & $(.00042)$ & $(.00042)$ \\
\hline$B A L K A N S$ & $19.4^{*}$ & $19.7^{*}$ & $19.6^{*}$ \\
\hline & $(2.38)$ & $(2.37)$ & $(2.37)$ \\
\hline$E A S T E R N E U$ & $10.5^{*}$ & $10.5^{*}$ & $10.5^{*}$ \\
\hline & $(1.67)$ & $(1.67)$ & $(1.67)$ \\
\hline$R^{2}$ & .877 & .877 & .877 \\
\hline$F$ statistic & 9.96 & 10.05 & 10.12 \\
\hline \hline
\end{tabular}

Note: ${ }^{*}$ and ${ }^{* *}$ respectively denote significance at the 5 percent and 10 percent levels. Source of conflict data: Brecke (1999). Duration of Muslim-Christian and Protestant-Catholic wars also predicted in the 1st stage, but not shown. 
Table 9.C: (Continued)

\begin{tabular}{||l|c|c|c||}
\hline \hline \multicolumn{1}{|c|}{ 1st Stage } & \multicolumn{3}{|c|}{ Dep. Var.: PROTESTANTCATHOLICW. } \\
\hline \hline ROME & $(1)$ & $(2)$ & $(3)$ \\
& -.0017 & -.0036 & -.0017 \\
& $(.013)$ & $(.013)$ & $(.013)$ \\
\hline JERUSALEM & -.005 & -.006 & -.005 \\
& $(.005)$ & $(.005)$ & $(.005)$ \\
\hline MECCA & -.0050 & -.006 & -.005 \\
& $(.019)$ & $(.019)$ & $(.019)$ \\
\hline$R O M E-J E R$ & -4.37 & -3.63 & -5.02 \\
& $(16.5)$ & $(16.4)$ & $(16.4)$ \\
\hline$J E R-M E C C$ & .000006 & .000007 & .000006 \\
& $(.000005)$ & $(.000005)$ & $(.000005)$ \\
\hline$R O M E-M E C C$ & .000007 & .000008 & .000007 \\
& $(.000013)$ & $(.000013)$ & $(.000013)$ \\
\hline$R M-J E-M E$ & -.0044 & -.0047 & -.0045 \\
& $(.0042)$ & $(.0042)$ & $(.0042)$ \\
\hline BALKANS & 1.78 & 1.70 & 1.82 \\
& $(2.35)$ & $(2.35)$ & $(2.34)$ \\
\hline$E A S T E R N E U$ & -.459 & -.361 & -.465 \\
& $(1.65)$ & $(1.65)$ & $(1.65)$ \\
\hline$R{ }^{2}$ & .307 & .299 & .305 \\
\hline$F$ statistic & .580 & .621 & .581 \\
\hline \hline
\end{tabular}

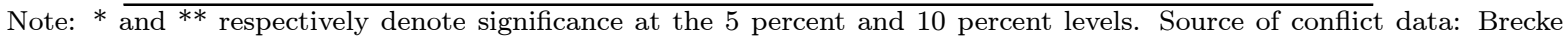
(1999). Duration of Muslim-Christian and Protestant-Catholic wars also predicted in the 1st stage, but not shown. 
Table 10: Impact of Conflicts on Polity Scores in 1994 (1400 - 1900 CE)

\begin{tabular}{|c|c|c|c|c|}
\hline & \multicolumn{4}{|c|}{ Dependent Variable: 1994 Polity Scores } \\
\hline & (1) & (2) & (3) & (4) \\
\hline TOTALCONFLICTS & $\begin{array}{l}-.036 \\
(.053)\end{array}$ & $\begin{array}{l}.054 \\
(.042)\end{array}$ & $\begin{array}{l}-.040 \\
(.126)\end{array}$ & $\begin{array}{l}-.334 \\
(.213)\end{array}$ \\
\hline MUSLIMCHRISTIAN & $\begin{array}{l}.414 \\
(.324)\end{array}$ & $\begin{array}{l}.913^{*} \\
(.227)\end{array}$ & $\begin{array}{l}1.134^{*} \\
(.507)\end{array}$ & $\begin{array}{l}1.570^{*} \\
(.712)\end{array}$ \\
\hline PROTESTCATHOLIC & $\begin{array}{l}-.085 \\
(.254)\end{array}$ & $\begin{array}{l}-.223 \\
(.303)\end{array}$ & $\begin{array}{l}-.329 \\
(.737)\end{array}$ & $\begin{array}{c}1.550 \\
(1.608)\end{array}$ \\
\hline POGROM & $\begin{array}{l}-1.09 \\
(2.11)\end{array}$ & $\begin{array}{c}-7.01^{*} \\
(1.99)\end{array}$ & $\begin{array}{l}-5.46 \\
(3.97)\end{array}$ & $\begin{array}{l}-2.42 \\
(5.61)\end{array}$ \\
\hline DURCONFLICTS & $\begin{array}{c}.188 \\
(.352)\end{array}$ & $\begin{array}{l}.095 \\
(.354)\end{array}$ & $\begin{array}{c}.135 \\
(.262)\end{array}$ & $\begin{array}{l}-.421 \\
(.385)\end{array}$ \\
\hline$\overline{D U R M U S L I M C H R I S T}$ & $\begin{array}{l}-.457 \\
(.373)\end{array}$ & $\begin{array}{l}-.440 \\
(.350)\end{array}$ & $\begin{array}{l}-.474 \\
(.511)\end{array}$ & $\begin{array}{l}-.804 \\
(.543)\end{array}$ \\
\hline DURPROTESTCATH & $\begin{array}{l}.491^{*} \\
(.239) \\
\end{array}$ & $\begin{array}{c}.342^{*} \\
(.256) \\
\end{array}$ & $\begin{array}{c}-2.40^{* *} \\
(.377)\end{array}$ & $\begin{array}{c}-.103 \\
(1.253) \\
\end{array}$ \\
\hline$\overline{D U R P O G R O M}$ & $\begin{array}{c}13.22 \\
(25.12)\end{array}$ & $\begin{array}{l}95.58^{*} \\
(35.06)\end{array}$ & $\begin{array}{c}77.21 \\
(57.01)\end{array}$ & $\begin{array}{c}-4319.2^{* *} \\
(2255.3)\end{array}$ \\
\hline$B A L K A N S$ & $\begin{array}{c}7.62 \\
(3.206)\end{array}$ & $\begin{array}{c}3.369 \\
(3.533)\end{array}$ & $\begin{array}{c}-.110 \\
(5.186)\end{array}$ & $\begin{array}{c}-2.22 \\
(6.289)\end{array}$ \\
\hline EASTERNEU & $\begin{array}{l}12.022^{*} \\
(2.836) \\
\end{array}$ & $\begin{array}{l}9.822^{*} \\
(3.851) \\
\end{array}$ & $\begin{array}{c}4.751 \\
(5.490) \\
\end{array}$ & $\begin{array}{c}6.592 \\
(5.833) \\
\end{array}$ \\
\hline$M I D E A S T$ & $\begin{array}{c}3.891 \\
(3.547)\end{array}$ & $\begin{array}{l}-1.609 \\
(3.730)\end{array}$ & $\begin{array}{c}8.553 \\
(6.239)\end{array}$ & $\begin{array}{l}10.948 \\
(7.312)\end{array}$ \\
\hline$A F R I C A$ & $\begin{array}{l}-4.319 \\
(3.203)\end{array}$ & $\begin{array}{l}-5.547 \\
(3.920)\end{array}$ & $\begin{array}{c}-.964 \\
(6.447)\end{array}$ & $\begin{array}{c}4.238 \\
(8.420)\end{array}$ \\
\hline$L A N D A R E A$ & $\ldots$ & $\begin{array}{c}-.0000009^{*} \\
(.0000002)\end{array}$ & $\begin{array}{c}-.0000009^{*} \\
(.0000004)\end{array}$ & $\begin{array}{c}-.000001 \\
(.0000004) \\
\end{array}$ \\
\hline MUSLIMAJOR & $\ldots$ & $\ldots$ & $\begin{array}{c}-.826 \\
(2.503)\end{array}$ & $\begin{array}{l}-3.361 \\
(4.681) \\
\end{array}$ \\
\hline CHRISTIANMAJOR & $\ldots$ & $\ldots$ & $\begin{array}{c}2.957 \\
(3.282)\end{array}$ & $\begin{array}{l}-1.391 \\
(4.524)\end{array}$ \\
\hline$R^{2}$ & .660 & .767 & .826 & .873 \\
\hline No. of obs. & 49 & 49 & 49 & 49 \\
\hline
\end{tabular}

Note: ${ }^{*}$ and ${ }^{* *}$ respectively denote significance at the 5 percent and 10 percent levels. Dependent variable: religious fractionalization in 2001; source: Alesina et al. (2003). Source of conflict data: Brecke (1999). Source of population data: McEvedy and Jones (1978). Geographic dummy variables WESTERNEU, CENTRALEU, ISLAND, NORTHERNEU included in all regressions but not shown. POPULATION, EQUATOR, LANDLOCK included in columns (2) through (4) but not shown. POP1000, POP1500, ROME, JERUSALEM, MECCA included in columns (3) and (4) but not shown. YRCONFLICT, YRMUSLIMCHRIST, YRPROTESTCATH and YRPOGROM included in column (4) but not shown. 
Table 11: Impact of Conflicts versus Fractionalization on Polity Sc. $(1400-1900$ CE)

\begin{tabular}{||l|c|c|c|c||}
\hline \hline & \multicolumn{4}{|c||}{ Dependent Variable: 1994 Polity Scores } \\
\hline \hline & $(1)$ & $(2)$ & $(3)$ & $(4)$ \\
\hline RELIGIOUSFRAC & 1.689 & 1.011 & -3.358 & 1.679 \\
& $(3.524)$ & $(2.830)$ & $(4.849)$ & $(4.286)$ \\
\hline ETH NOFRAC & $-10.32^{*}$ & $-8.316^{*}$ & $-7.452^{*}$ & -2.377 \\
& $(4.669)$ & $(3.991)$ & $(3.323)$ & $(5.193)$ \\
\hline LINGOFRAC & -0.704 & .907 & 3.728 & -2.267 \\
& $(5.489)$ & $(4.182)$ & $(4.860)$ & $(6.574)$ \\
\hline TOTALCONFLICTS & -.0452 & .025 & -.026 & -.115 \\
& $(.034)$ & $(.025)$ & $(.069)$ & $(.109)$ \\
\hline MUSLIMCHRISTIAN & .154 & $.394^{*}$ & .422 & -.115 \\
& $(.171)$ & $(.159)$ & $(.292)$ & $(.326)$ \\
\hline PROTESTCATHOLIC & .037 & -.014 & -.138 & -.969 \\
& $(.206)$ & $(.159)$ & $(.428)$ & $(.729)$ \\
\hline POGROM & 2.931 & .042 & .973 & $-10.879^{*}$ \\
& $(2.249)$ & $(2.095)$ & $(3.194)$ & $(5.755)$ \\
\hline DURCONFLICTS & 1.128 & .498 & .549 & .385 \\
& $(.717)$ & $(.604)$ & $(.735)$ & $(.828)$ \\
\hline DURMUSLIMCHRIST & -.426 & -.052 & -.274 & -.570 \\
& $(.429)$ & $(.463)$ & $(.730)$ & $(.696)$ \\
\hline DURPROTESTCATH & .070 & .209 & .210 & -.127 \\
& $(.200)$ & $(.128)$ & $(.190)$ & $(.342)$ \\
\hline DURPOGROM & -4.737 & -.402 & 1.798 & -2.212 \\
& $(3.774)$ & $(3.904)$ & $(6.662)$ & $(11.151)$ \\
\hline AFRICA & $-2.643^{*}$ & -4.639 & .531 & -22.156 \\
& $(4.520)$ & $(4.034)$ & $(5.99)$ & $(23.30)$ \\
\hline LANDAREA & $\ldots$ & $.0000008^{*}$ & .0000006 & $-.000001^{* *}$ \\
& & $. .0000002)$ & $(.0000004)$ & $(.0000005)$ \\
\hline MUSLIMAJOR & $\ldots$ & $\ldots$ & -.322 & -1.281 \\
& & & $(2.847)$ & $(4.782)$ \\
\hline CHRISTIANMAJOR & $\ldots$ & $\ldots$ & 2.631 & .561 \\
& & & $(3.784)$ & $(6.803)$ \\
\hline$R^{2}$ & .764 & .818 & .859 & .909 \\
\hline No. of obs. & 48 & 48 & 48 & 48 \\
\hline \hline
\end{tabular}

Note: ${ }^{*}$ and ${ }^{* *}$ respectively denote significance at the 5 percent and 10 percent levels. Dependent variable: religious fractionalization in 2001; source: Alesina et al. (2003). Source of conflict data: Brecke (1999). Source of population data: McEvedy and Jones (1978). Geographic dummy variables WESTERNEU, CENTRALEU, NORTHERNEU, ISLAND, BALKANS, MIDDLEAST included in all regressions but not shown. POPULATION, EQUATOR, LANDLOCK included in columns (2) through (4) but not shown. POP1000, POP1500, ROME, JERUSALEM, MECCA included in columns (3) and (4) but not shown. YRCONFLICT, YRMUSLIMCHRIST, YRPROTESTCATH and YRPOGROM included in column (4) but not shown. 